\title{
HUNG OUT TO DRY? ATTORNEY- CLIENT CONFIDENTIALITY AND THE REPORTING DUTIES IMPOSED BY THE FINANCIAL INTELLIGENCE CENTRE ACT 38 OF 2001
}

\author{
Daleen Millard \\ Blur LLB LLM LLD \\ Professor of Private Law \\ University of Johannesburg \\ Viviana Vergano* \\ LLB LLM
}

\section{SUMMARY}

According to the South African Law Reform Commission, money laundering is the manipulation of illegally acquired wealth in order to obscure its true source or nature. This is achieved by performing a series of transactions with the proceeds of criminal activities that, if successful, will leave the illegally derived proceeds appearing as a product of legitimate transactions or investments. Professional money laundering assists and strengthens organised crime and may contribute to the undermining of the civil society and the financial system of a country. Attorneys as professionals are no doubt in a precarious position. On the one hand there is the duty to keep in confidence private information pertaining to clients' affairs which is no doubt essential to the attorney-client relationship and on the other hand there is the duty to the community to uphold the ethics of the profession. Attorneys may find that they are caught between these seemingly conflicting duties and the question is which duty is more important. This article weighs the newly-imposed duties on the legal profession pertaining to money laundering against the equally important principle of attorney-client privilege and asks whether it is possible to reconcile anti-money laundering obligations with legal professional privilege. The article considers the latter duty in light of the ethics of the legal profession in South Africa and the foundation of legal professional conduct. In addition, the position in the United Kingdom and in Canada is also considered. Against this background it is argued that there is no need to regulate the South African professional legal industry any further. Until FICA's reporting provisions are formally challenged in the Constitutional Court, attorneys will continue to remain uncertain as to their position, notwithstanding the fact that guidance notes have been issued to aid attorneys in this regard. In order to comply with FICA and simultaneously preserve the attorney-client relationship, attorneys need to educate clients on the provisions of FICA. Furthermore, legal practitioners should have a sound legal knowledge of FICA in order help the State combat organised crime and laundering activities. Finally, it is advisable to keep up to date with the latest guidelines which regarding the independence of the profession; possible infringements of the fundamental right to privacy and potential threats to the confidential attorney-client relationship. It is the awareness of this 
precarious balance that will ensure compliance with the FICA without causing the attorneys' profession to lose its credibility.

\section{$1 \quad$ INTRODUCTION}

The term "money laundering" has been coined first by US treasury agents trying to catch Al Capone in the 1930s, ${ }^{1}$ and is said to stem from Mafia ownership of laundromats in the United States of America during the Prohibition. ${ }^{2}$ The profits derived from illicit activities such as bootlegging, gambling and prostitution were intermingled with the legitimate profits of the laundromat business, and the illicit profits were attributed to legitimate activities. ${ }^{3}$ Through this process of money laundering, criminals attempt to find a way of enjoying the proceeds of crime in an undetected manner, thus transforming the proceeds into "legitimate" business."

De Koker refers to money laundering in general as any act that obscures the illicit nature or the existence, location or application of the proceeds of crime. ${ }^{5}$ Sophisticated laundering schemes normally require assistance from professional advisors with legal, accounting, banking and/or financial expertise or general business acumen. ${ }^{6}$ Financial Action Task Force ${ }^{7}$ reports on money laundering also mention that professional intermediaries such as attorneys are used to launder money. ${ }^{8}$

It is expected of legal practitioners to be fit and proper persons and act in a professional and honest manner. Unfortunately these general, ethical and moral standards do not prevent some legal practitioners from engaging in criminal activities. In fact, attorneys are in an ideal position to commit crimes because of their access to trust accounts. Professional money laundering assists and strengthens organized crime and may contribute to the undermining of the civil society and the financial system of a country. ${ }^{9}$ See for instance $S$ v Dustigar, ${ }^{10}$ where a practicing attorney, Nugalen Gopal Pillay,

* This article is based on Ms Vergano's minor dissertation entitled: "The Effects of Money Laundering Reporting Provisions on Legal Professional Ethics: Is the Administration of Justice being Thwarted?" The dissertation was submitted in partial fulfillment of the requirements of the LLM degree in Banking Law at the University of Johannesburg.

1 Hubschle "Terrorist financing in Southern Africa: Are we Making a Mountain Out of a Molehill?" 2007 Institute for Security Studies 11.

2 Bourne "Money Laundering: What is Being Done to Combat it? A Comparative Analysis of the Laws in the United States of America, the United Kingdom and South Africa" 2002 SAMLJ 475 475.

3 Bourne 2002 SAMLJ 475.

4 Burdette "Is the Reporting Obligation of Attorneys in terms of Section 29 of the Financial Intelligence Centre Act 38 of 2001 a Myth or a Reality?" 2010 University of Pretoria research paper 15.

5 De Koker KPMG South African Money Laundering and Terror Financing Law (2011) com 4.

De Koker KPMG South African Money Laundering and Terror Financing Law com 1-7.

Hereinafter "the FATF" http://www.fatf-gafi.org (accessed 2012-10-24).

Burdette 2010 University of Pretoria research paper 9.

9 De Koker KPMG South African Money Laundering and Terror Financing Law com 1-7.

10 Case no 6/2000 (DCLD) (unreported). In casu nineteen people were convicted for their involvement in the biggest armed robbery in South Africa's history. One of the robbers who turned state witness testified that the accused approached him and offered him an investment opportunity in a night club. The attorney then brokered the deal between the sellers and the witness. He drafted the sale agreement in which the name of the purchaser was left blank. He then handed R500 000 in cash to the sellers at his office as a deposit in terms of the 
operated a money-laundering scheme and was sentenced to five years' imprisonment. ${ }^{11}$

Attorneys are no doubt in a precarious position. On the one hand there is the duty to keep in confidence private information pertaining to clients' affairs which is no doubt essential to the attorney-client relationship and on the other hand there is the duty to the community to uphold the ethics of the profession. Attorneys may find that they are caught between these seemingly conflicting duties and the question is which duty is more important. This article weighs the newly imposed duties on the legal profession pertaining to money laundering against the equally important principle of attorney-client privilege and asks whether it is possible to reconcile anti-money-laundering obligations with legal professional privilege. As a matter of background, the article provides a brief historical overview of money laundering and explains the term within the current conceptual framework in South Africa. In addition, the nature, structure and stages of money laundering are discussed together with a brief overview of the legislative framework of money laundering in South Africa, with the main focus on the Financial Intelligence Centre Act. ${ }^{2}$ Those provisions of FICA that regulate the legal profession are the main focus of the discussion and specific mention is made of the key concepts "accountable institution", "reportable institution", and "supervisory bodies" and the duties imposed on attorneys by FICA. These duties are viewed against the conflict between statutory antimoney-laundering provisions and the attorney's duty towards clients not to disclose privileged information. The article explains the latter duty in light of the ethics of the legal profession in South Africa and the foundation of legal professional conduct.

In this article mention is alo made of international standards and measurements in the form of treaties and conventions and the current position the United Kingdom and Canada is discussed.

\section{DEFINING AND CONTEXTUALIZING MONEY LAUNDERING}

Money laundering has attracted a number of definitions. According to the Chairperson of the Australian National Crime Authority and former president of the FATF, Tom Sherman, money laundering is the process of converting or "cleaning" property knowing that such property is derived from serious crime for the purpose of disguising its origin. ${ }^{13}$ The South African Law Reform Commission defined money laundering as follows: ${ }^{14}$

"the manipulation of illegally acquired wealth in order to obscure its true source or nature ... [which] is achieved by performing a number of transactions with the proceeds of criminal activities that, if successful, will leave the illegally derived proceeds appearing as a product of legitimate investments or transactions."

agreement. He drafted another sham agreement in the name of another purchaser and also manipulated his trust-account records to hide the identity of the purchaser and the actual amounts that were paid.

11 Goredema Profiling Money Laundering in Eastern and Southern Africa Monograph No 90 (2003) 95.

1238 of 2001 (hereinafter "FICA").

13 Bourne 2002 SAMLJ 476.

14 Van der Westhuizen "FICA for Attorneys" October 2003 De Rebus 3333. 
The conceptual framework and difficulties becomes a bit clearer when one considers the structure and stages of money laundering. Criminal money or the proceeds of crime may be divided into three categories and each category depicts criminal activities that differ both in form of appearance, and on their impact on society.

The first, hot money or "legal-illegal money" is money that was initially obtained legally but subsequently became illegal, ${ }^{16}$ an example of which is tax evasion. ${ }^{17}$ The second category consists of money that was obtained in an illegal manner and was subsequently used in a legal manner. ${ }^{18}$

"Dirty money" falls into the third category and consists of money that is obtained from crime and employed either for illegal purposes or for infiltration into the legal financial world by making seemingly legal investments. ${ }^{19}$ This category relates to organized crime and the money is referred to as "illegalillegal money" or dirty money. ${ }^{20}$

As far as the actual process is concerned, money laundering occurs generally in three stages, namely placement, layering and integration. ${ }^{21}$ The proceeds of crime enter the financial system during the placement stage where the criminal then moves the proceeds to another location and where placement can take place with greater safety. ${ }^{22}$ Usually, if it is a large amount, it is then split up into smaller amounts which are then deposited into different bank accounts without raising suspicion. ${ }^{23}$ This process which is referred to as "smurfing" or "structuring" is criminalized by section 64 of FICA and is often employed in countries where all transactions involving large amounts of cash must be reported. ${ }^{24}$

After the placement of money, it is then layered by means of a complex series of transactions which are aimed at blurring the trail of money; thus separating the illicit proceeds from their criminal source. ${ }^{25}$

The final stage involves the integration of all the funds where the original amount minus the costs of the laundering process is amassed and placed

15 Van Jaarsveld "Mimicking Sisyphus? An Evaluation of the Know Your Customer Policy" 2006 Obiter 228229

16 Ibid

17 Ibid. The money is earned legally as remuneration for services rendered, for example, and then becomes illegal when the taxpayer does not declare such income to the South African Revenue Services. The taxpayer then purchases a new motor vehicle with this money or transfers the money in his attorney's trust account and in so doing, launders the money.

$18 \mathrm{Ibid}$. An example of this is a legitimate organization that commits fraud and the illegally obtained money is then placed back into the organization and employed for legitimate business activities, such as for example the payment of salaries, thus "illegal-legal money".

19 Ibid.

20 Ibid.

21 De Koker KPMG South African Money Laundering and Terror Financing Law com 6.

22 Ibid.

Ibid.

Ibid.

$25 \mathrm{Ibid}$. De Koker demonstrates that layering may take place through the drawing of money from one account at one bank, splitting the amount and depositing it into three different accounts at three other banks; the purchasing of property and selling it soon afterwards; and the depositing of money into a trust account of an attorney and then requesting it to be paid or repaid into other personal accounts. 
under the control of the criminal as apparent legitimate business funds. ${ }^{26}$ The aforementioned costs include bank costs, taxes and any commission payable on transactions. ${ }^{27}$ The further ahead the criminal advances over these stages, the more difficult it becomes to detect money laundering, hence the enactment of FICA and the reporting provisions thereof.

Although these stages can be identified in many sophisticated moneylaundering schemes, not all schemes necessarily reflect these stages. ${ }^{28}$

The Centre for the Study of Economic Crime at the Rand Afrikaans University ${ }^{29}$ (as it was formerly known) released a report on money-laundering trends in March 2002 based on the perceptions of a group of expert investigators of economic crime who attended a workshop in December 2001. ${ }^{30}$ The use of professional assistance was one of the themes outlined by De Koker in this report on money-laundering trends which was published as part of a monograph series by the Institute for Security Studies. Many laundering schemes are too complicated to be planned and executed by the criminals themselves. Knowledgeable individuals such as real estate agents, attorneys and accountants assist criminals to launder money. ${ }^{31}$

Technological aids that enable money laundering include the internet, online banking and new electronic payment technologies such as "cash send" or "money gram", where an automatic teller machine is used to send cash to other accounts. Add to these the use of shell companies, trading in and false invoicing for the supply of goods or services, real estate, art, diamonds, and gold and other precious metals and tried and trusted methods evolve constantly to thwart law-enforcement efforts. ${ }^{32}$ Money-laundering activities can also take place through various abusers of informal banking and financial channels, and alternative remittance systems ${ }^{33}$ which are financial services, traditionally operating outside the conventional financial sector, where value or funds are moved from one geographic location to another. These informal systems generally operate outside the regulatory system that applies to financial institutions. ${ }^{34}$ They allow users to transfer money or value across borders with minimal or no physical movement of money or paper transactions. ${ }^{35}$ Although these systems serve legitimate purposes, they provide a high level of anonymity and can be abused by money launderers and terrorist

Ibid.

Ibid.

28 Ibid. In South Africa, eg, many of the laundering schemes consist only of placement, where criminals will simply deposit ill-gotten cash into a bank account and later withdraw the money and then spend it.

29 Currently known as the University of Johannesburg.

30 Goredema Profiling Money Laundering in Eastern and Southern Africa Monograph No 9089. the depositing of money into a trust account of an attorney and then requesting it to be paid or repaid into other personal accounts.

31 Goredema Profiling Money Laundering in Eastern and Southern Africa Monograph No 9094.

32 Moshi "Fighting Money Laundering in Africa" 2007 Institute for Security Studies 12 . The author notes that, if banks are used, the transactions tend to involve small amounts of uncomplicated layering of funds of which the much-cited 9/11 atrocities in the United States provided a classic example. An examination of the hijackers' finances revealed that the individual transactions were small, falling below the reporting threshold for unusual cash transactions, and the funds involved added up to less than half a million US dollars.

33 Moshi 2007 Institute for Security Studies 2.

34 Ibid.

35 Ibid. 
organizations to escape the scrutiny of financial regulators and lawenforcement agencies. ${ }^{36}$ The next paragraph sketches the South African legislative framework as the first line of defence against such criminal activities.

\section{LEGISLATIVE FRAMEWORK AND ATTORNEYS' COMPLIANCE STRUCTURES}

In April 1996, a money-laundering project was launched to focus on the administrative measures to combat money laundering in South Africa. ${ }^{37}$ The Law Commission subsequently formulated a report on money laundering and revised the Money Laundering Control Draft Bill resulting in FICA, which is now the main anti-money-laundering statute in South Africa. ${ }^{3}$

South Africa's anti-money-laundering regime is based upon internationally established rules, procedures and guidelines. ${ }^{39}$ FICA imposes certain duties on institutions such as banks and attorneys. These duties are, by necessity, interdependent and complementary. Furthermore, FICA establishes a Financial Intelligence Centre and a Money Laundering Advisory Council The latter advises Government on policies and measures to combat money laundering. ${ }^{40}$ The FIC's functions include processing and analysing information that it receives from accountable institutions regarding money-laundering activities; giving guidance to these institutions; and supervising compliance with moneylaundering laws. ${ }^{41}$ The FIC also issues guidance notes regarding compliance to the FICA legislation. ${ }^{42}$

The Financial Intelligence Centre Amendment $\mathrm{Act}^{43}$ which came into force on 1 December 2010, made extensive amendments to FICA providing for more regulatory, supervisory and enforcement powers for the FIC and supervisory bodies. ${ }^{44}$ Moreover, FICAA inserted section $1 \mathrm{~A}$ into FICA which provides that the provisions of FICA will prevail if there is any conflict between FICA and any other law existing at the commencement of FICA, save of course, for the Constitution of the Republic of South Africa. ${ }^{45}$

Although South Africa lacked general money-laundering-control frameworks before the adoption of FICA, the important building blocks of a compliance system had already been in place for some time. ${ }^{46}$

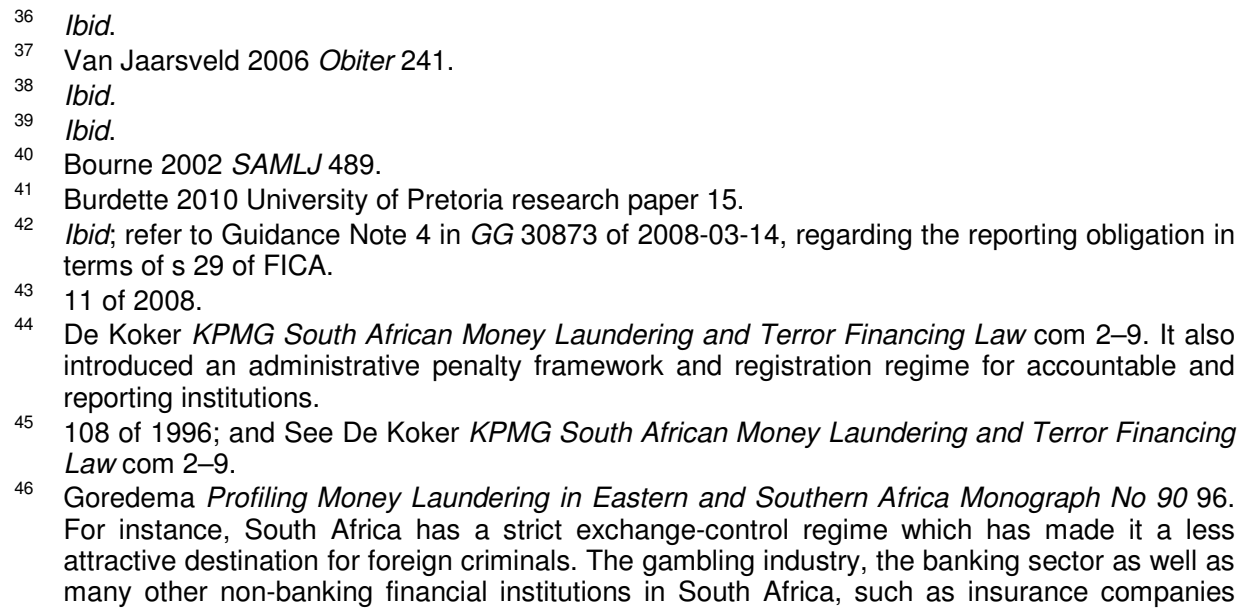

44 De Koker KPMG South African Money Laundering and Terror Financing Law com 2-9. It also introduced an administrative penalty framework and registration regime for accountable and reporting institutions.

45108 of 1996; and See De Koker KPMG South African Money Laundering and Terror Financing Law com 2-9.

46 Goredema Profiling Money Laundering in Eastern and Southern Africa Monograph No 9096. For instance, South Africa has a strict exchange-control regime which has made it a less attractive destination for foreign criminals. The gambling industry, the banking sector as well as many other non-banking financial institutions in South Africa, such as insurance companies 
The introduction of the concepts "reportable" and "accountable" institutions is important. Apart from providing for the establishment and operation of the FIC and the MLAC, FICA creates money-laundering-control obligations and regulates access to information. ${ }^{47}$ The obligations are primarily applicable to accountable institutions although some extend to reporting institutions, to all persons involved in businesses and to international travellers. ${ }^{48}$ Schedule 1 to FICA lists all the accountable institutions and includes inter alia attorneys as defined in the Attorneys Act. ${ }^{49}$ Section 1 of this act defines an attorney as "any person duly admitted to practice as an attorney in any part of the Republic." Attorneys who are not currently practising but who are academics or legal advisers are also brought within the ambit of FICA. ${ }^{50}$ Accountable institutions are saddled with the onerous compliance obligations that are created by FICA, such as the appointment of a compliance officer and the drafting of internal compliance rules. ${ }^{51}$ Accountable institutions can be distinguished from reportable institutions and supervisory bodies within the ambit of FICA. Schedule 3 of FICA lists only two reportable institutions, namely a person who carries on the business of dealing in motor vehicles and a person who carries on the business of dealing in Kruger Rands. The relevant supervisory bodies listed in Schedule 2 to FICA will perform the supervisory functions ${ }^{52}$ such as reporting to the FIC any suspicious transactions concluded by any of the institutions they supervise.

Attorneys have always been accountable to the The Law Society of South Africa ("LSSA") as the attorney's supervisory body. In May 2008, when the LSSA made submissions ${ }^{54}$ to the Parliamentary Portfolio Committee on Finance with regards to the FIC Amendment Bill on behalf of the attorney's profession, it stressed that, although the organized profession supported the broad social campaign against money laundering and terrorism, the Bill, if implemented, would represent a significant attack on the basic rights such as the right to privacy, and the right to a fair trial. ${ }^{55}$ The objections expressed by the LSSA in this regard were that it could lead to members of the public losing confidence in the independence of the profession and the confidential nature of the relationship with attorneys. ${ }^{56}$ Furthermore, the LSSA urged Parliament to take such necessary steps to give recognition to the independence of the legal profession and the rule of law in the Bill. ${ }^{57}$ The LSSA also highlighted a number of concerns. For instance, dealing of information and documents protected by legal professional privilege and confidentiality, and the obligation placed on an

and foreign exchange dealers already have a number of money-laundering-control obligations. A discussion of these institutions, however, is beyond the scope of this article.

47 Goredema Profiling Money Laundering in Eastern and Southern Africa Monograph No 9098.

48 Ibid.

4953 of 1979. See Goredema Profiling Money Laundering in Eastern and Southern Africa Monograph No 9098.

Ibid.

51 lbid.

52 Goredema Profiling Money Laundering in Eastern and Southern Africa Monograph No 9098.

53 Bourne 2002 SAMLJ 490.

54 The LSSA's full submissions on the FIC Amendment Bill www.lssa.org.za.

55 Van der Westhuizen "LSSA Urges Parliament to Respect Professional Legal Confidentiality, Independence of the Profession and the Rule of Law in Amending FICA" June 2008 De Rebus 18.

56 Van der Westhuizen June 2008 De Rebus 18.

57 Ibid. 
attorney to keep confidential the affairs of a client. were not adequately addressed in the Bill. ${ }^{58}$ Practical experience has taught that this complicated distinction represents a difference between a transaction required to be reported to the FIC in terms of section 29 of FICA or not. ${ }^{59}$ The danger exists that the attorney may report in fear of non-compliance, thereby depriving the client both of an existing privilege and the opportunity to obtain advice as the existence and breach of such privilege. ${ }^{60}$

Herein lies the difficulty: The duties of legal professionals' conflict with the duty that is owed to their clients, weighed against the duty towards public interest. The LSSA is well aware of the concerns expressed by many legal professionals with regard to the fact that the profession may well be seriously undermined in the light of anti-money-laundering provisions. Legal professionals consider these provisions to be highly intrusive. ${ }^{61}$

This tension becomes clearer if one considers the duties on accountable institutions. The next paragraph takes a look at these.

\section{DUTIES OF ACCOUNTABLE INSTITUTIONS}

\section{General overview}

The duties set out in FICA are the duty to identify clients and other persons, ${ }^{62}$ the duty to keep records of business relationships and transactions, ${ }^{63}$ the reporting duties and access to information, ${ }^{64}$ the measures to promote compliance by accountable institutions ${ }^{65}$ and referral and supervision. ${ }^{66}$

Accountable institutions are required to comply with certain procedures when entering into transactions with clients. These include establishing the identity of a client and, where the client is acting as an agent, ${ }^{67}$ also the identity of the principal ${ }^{68}$ keeping record of the client's identity and the nature of the transaction for a period of at least five years; ${ }^{69}$ reporting to the FIC any cash transactions or electronic transfers in excess of a prescribed amount; ${ }^{70}$ and to report any transactions suspected to involve the proceeds of an unlawful activity. ${ }^{7}$

Furthermore, section 42 of FICA requires every accountable institution to formulate and implement internal rules concerning a number or matters, ${ }^{72}$ such




as the establishment and verification of the identity of persons which it must identify in terms of FICA, ${ }^{73}$ the information of which record must be kept in terms of $\mathrm{FICA}^{74}$ and how and where those records must be kept. ${ }^{75}$ In addition, it prescribes the steps to be taken to determine when a transaction is reportable to ensure that the institution complies with its reporting duties under FICA $^{76}$ and other matters as may be prescribed by regulation.

An accountable institution must provide training to its employees to enable them to comply with FICA and the relevant internal rules. ${ }^{78}$ In addition, someone must be appointed whose responsibility it is to ensure that the employees of the institution comply with FICA and the internal rules as well as compliance by the accountable institution with its obligations under FICA. ${ }^{79}$ This individual is normally referred to as a compliance officer.

Internal rules must comply with the requirements prescribed by $\mathrm{FICA}^{80}$ and the regulations thereto, and must be made available to every person employed by the accountable institution who may be involved in transactions to which FICA applies. ${ }^{81}$ In addition, internal rules must set out in detail the procedures to guide the compliance officer and employees in their duties in terms of FICA. ${ }^{82}$ Attorneys, as accountable institutions, must on request make a copy of their internal rules available to the FIC or to the LSSA. ${ }^{83}$ In order to assist the attorneys in drafting internal rules, the LSSA has posted a precedent set of internal rules on its website. ${ }^{84}$

There is a serious responsibility on an accountable institution to handle the FICA process correctly, particularly so as there are massive fines levied by the FIC for non-compliance. ${ }^{85}$ Compliance officers assigned with the responsibility of ensuring compliance with FICA in assisting management and the employees to discharge their duties will do so by designing and operating appropriate systems. ${ }^{86}$ The person so appointed is responsible not only for making sure that the business complies with FICA but that the employees do so as well. ${ }^{87}$

Owing to the onerous nature of a compliance officer's duties, compliance officers have demonstrated an unwillingness to accept this appointment as they are reluctant to shoulder this burden unless they are given all the powers and resources that will be required to enable them to ensure compliance. ${ }^{88}$ It is

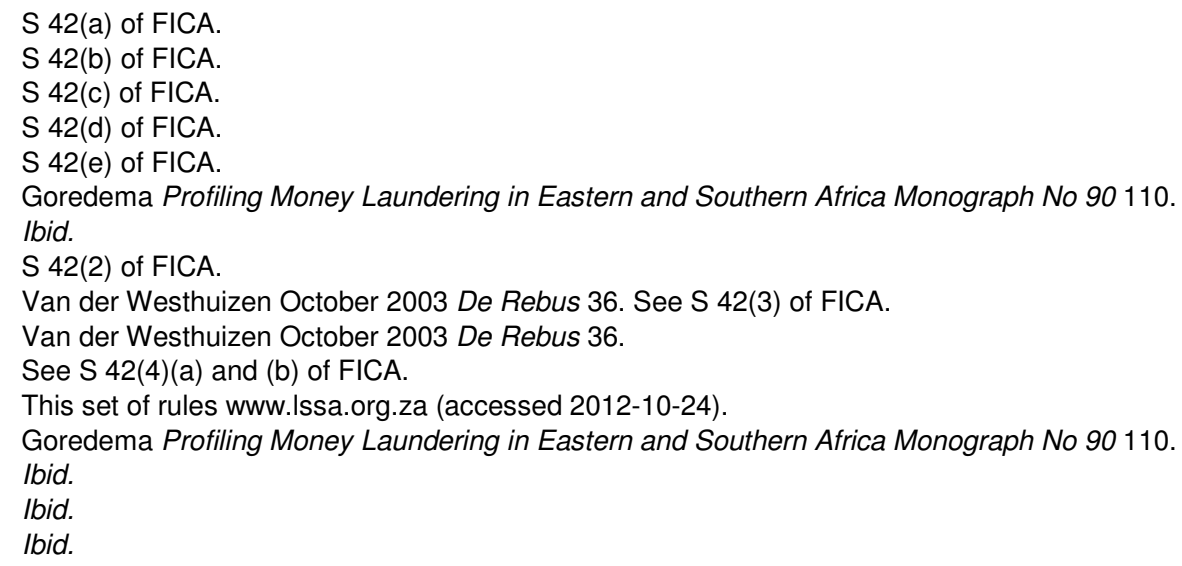


probable therefore, that the managing directors of many companies will be appointed as the responsible officers.

\section{Specific duties under FICA}

The first specific duty is to identify clients. Section $21(1)$ of FICA $^{90}$ requires an accountable institution to establish and verify the identity of a prospective client before establishing a business relationship or concluding a single transaction with a client and, if necessary, the identity and the authority of the client's agent or principal. ${ }^{91}$ Section 21 prohibits accountable institutions from conducting business with unidentified clients, and they are accordingly instructed to obtain a certain amount of information about a potential client, and to verify its authenticity before accepting a customer. ${ }^{92} \mathrm{~A}$ "business relationship" is defined in FICA as "an arrangement between a client and an accountable institution for the purpose of concluding transactions on a regular basis."

FICA and the Regulations thereto enable the FIC to issue guidance notes to accountable institutions regarding FICA obligations of which the first, issued in 2004, must be considered when the identification and verification scheme is analysed. ${ }^{93}$ The Regulations to FICA contain "prescribed steps" which an accountable institution needs to adhere to so that it may obtain the full names, date of birth, identity number and residential address of a prospective client who is a South African citizen or resident, the verification of which is to be compared with the information in that person's official South African identity document, and if believed necessary, even with the credit bureau. ${ }^{94}$ These steps amount to what is commonly referred to in practice as "know your client." 95

Even though FICA compels accountable institutions to establish the identity of their clients, accountable institutions are not explicitly required to probe further and to establish their clients' sources of funds, occupation, business, or net worth. ${ }^{96}$ It may be implied given the overall purpose of FICA and the other specific duties. The FIC has not been completely silent on the procedure that must be followed in this respect. On 21 April 2004, the FIC posted a general guidance note concerning the identification of clients which can be found on its website $^{97}$ and which, in essence, provides that institutions are not required to follow "a one-size-fits-all" approach in the methods they use and the levels of verification they apply to all relevant clients. ${ }^{98}$

Ibid.

This section came into operation on 30 June 2003.

Goredema Profiling Money Laundering in Eastern and Southern Africa Monograph No 90101.

Van Jaarsveld 2006 Obiter 242.

De Koker "Client identification and money laundering control: perspectives on the Financial Intelligence Centre Act 38 of 2001" 2004 TSAR 715717.

94 De Koker 2004 TSAR 718.

95 It is also important to note that the identification and verification of clients do not only apply to new clients, but according to s 21(2) of FICA, after 30 June 2004, an institution may also not conclude a transaction in the course of its business relationship with an unidentified current client, until it has established and verified that client's identity, as prescribed.

96 Goredema Profiling Money Laundering in Eastern and Southern Africa Monograph No 90101.

97 www.fic.gov.za (accessed 2012-10-24).

98 Van der Westhuizen "Some Rules of Thumb" July 2004 De Rebus 3434. 
Overall, a "risk-based approach" is advocated, allowing an institution to exercise its judgment based on the particular risk profile of a client, and to decide what the appropriate balance is between the level of verification and the most practical means to obtain such verification where "the greater the risk, the higher the level of verification, and the more secure the methods of verification used, must be". ${ }^{99}$

The second duty places an obligation on attorneys and other institutions to keep records of specific details regarding clients, agents, and principals as well as their transactions for a period of at least five years. ${ }^{100}$ An accountable institution must also take reasonable steps in respect of existing business relationships to maintain the correctness of particulars which are susceptible to change. ${ }^{101}$ Section $46(2)$ read with section $68(1)$ of FICA provided that an institution that concludes a transaction in contravention of this prohibition commits an offence and is liable to a fine not exceeding one hundred million Rand or imprisonment of up to 15 years.

The duty to report in the third instance entails reporting of transactions involving cash amounts in excess of a prescribed amount being an amount over twenty-five thousand Rand (R25 000.00), suspicious and unusual transactions, the conveyance of cash across the borders of South Africa and electronic transfers of money by accountable institutions. ${ }^{102}$ The introduction of FICA impinges upon the traditional role and independence of the attorney's profession and upon the confidentiality of all communications between attorneys and their clients. This is most evident when discussing this particular duty. This again returns to the crux of this discussion: The onerous reporting duties that attorneys face versus the protection that attorneys owe to their clients in respect of confidential communications.

In the fourth instance are the duties in sections 27 and 28 of FICA. ${ }^{103}$ Section 27 states that an accountable institution must inform the FIC whether: a specified person is or has been a client of the accountable institution; a specified person is acting or has acted on behalf of any client of the accountable institution, or if a client of the accountable institution is acting or has acted for a specified person. Section 28 of FICA governs situations where "an accountable and reporting institution, must within the prescribed period, report to the Centre the prescribed particulars concerning a transaction concluded with a client if the cash transaction is in excess of the prescribed amount" and is either paid by the accountable or reporting institution to the client, or to a person acting on behalf of a client, or to a person on whose behalf the client is acting or vice versa.

99 Ibid.

100 S 23 of FICA. In addition, attorneys are obliged to make such records available to the FIC on the strength of a warrant, to inform the centre on request of the existence of a current or past mandate, to report cash transactions above a prescribed amount to the FIC; and to report to the FIC the conveyance in terms of a transaction with a client of cash above a prescribed amount or through a specified account or institution. See Hoffmann Legal Education And Development, Law Society of South Africa Professional Conduct (2012) 27.

101 Van der Westhuizen July 2004 De Rebus 34.

102 Goredema Profiling Money Laundering in Eastern and Southern Africa Monograph No 90102. De Koker KPMG South African Money Laundering and Terror Financing Law com 7-5.

10338 of 2001. 
The fifth duty is contained in section 29(1) of FICA and is considered the most onerous of the reporting duties. It provides as follows: ${ }^{104}$

"(1) A person who carries on a business or is in charge of a business or who is employed by a business and who knows or ought reasonably to have known or suspected that -

(a) the business has received or is about to receive the proceeds of unlawful activities or property which is connected to an offence relating to the financing of terrorist-related activities;

(b) a transaction or series of transactions to which the business is a party -

i. facilitated or is likely to facilitate the transfer of the proceeds of unlawful activities or property which is connected to an offence relating to the financing or terrorist related activities;

ii. has no apparent business or lawful purpose;

iii. is conducted for the purpose of avoiding giving rise to a reporting duty under this Act;

iv. may be relevant to the investigation of an evasion or attempted evasion of a duty to pay any tax, duty or levy imposed by legislation administered by the Commissioner for the South African Revenue Service; or

v. relates to an offence relating to the financing of terrorist and related activities; or

(c) the business has been used or is about to be used in any way for money laundering purposes or to facilitate the commission of an offence relating to the financing of terrorist related activities, must, within the prescribed period after the knowledge was acquired or the suspicion arose, report to the Centre the grounds for the knowledge or suspicion and the prescribed particulars concerning the transaction or series of transactions."

"Transaction" is defined in FICA as "a transaction concluded between a client and an accountable institution in accordance with the type of business carried on by that institution". It is argued that "a core portion of section 29 will be rendered meaningless if this definition is applied to section 29 and that this definition leaves scope for an argument that a suspicious transaction is not reportable because the business which is party to that transaction is not an accountable institution or, if it is an accountable institution, that the transaction is not concluded in accordance with the type of business carried on by that

104 The reporting obligation in terms of $\mathrm{s} 7$ of the POCA was replaced by $\mathrm{s} 29$ reporting obligation in terms of FICA, which came into effect on 3 February 2003.

105 The remainder of $S 29$ stipulates: "A person who carries on a business or is in charge of or manages a business or who is employed by a business and who knows or suspects that a transaction or a series of transactions about which enquiries are made, may, if that transaction or those transactions had been concluded, have caused any of the consequences referred to in subsection (1)(a), (b) or (c), must, within the prescribed period after the knowledge was acquired or the suspicion arose, report to the Centre the grounds for the knowledge or suspicion and the prescribed particulars concerning the transaction or series of transactions" (s 29(2)). S 29(3) provides that no person who made or must make a report in terms of s 29 may disclose that fact or any information regarding the contents of any such report to any other person, including the person in respect of whom the report is or must be made, "otherwise than - (a) within the scope of the powers and duties of that person in terms of any legislation; (b) for the purpose of carrying out the provisions of this Act; (c) for the purpose of legal proceedings, including any proceedings before a judge in chambers; or (d) in terms of an order of court". In accoradnce with s 29(4), no person who knows or suspects that a report has been or is to be made in terms of $s 29$ may disclose that knowledge or suspicion or any information regarding the contents of any such report to any other person, including the person in respect of whom the report is or is to be made, "otherwise than (a) within the scope of the powers and duties of that person in terms of any legislation; (b) for the purpose of carrying out the provisions of this Act; (c) for the purpose of legal proceedings, including any proceedings before a judge in chambers; or (d) in terms of an order of court". 
institution". ${ }^{106}$ Van der Westhuizen agrees with de Koker's view in this regard, and that the word "transaction" should be given its ordinary, grammatical meaning. ${ }^{107}$ This is one of the rules of statutory interpretation. ${ }^{10}$

In terms of section 33 of FICA, accountable institutions, reporting institutions or persons required to make a report to the FIC in terms of sections 28 or 29 of FICA, may continue with the transactions in respect of which the report is required to be made unless the FIC directs otherwise. ${ }^{109}$ Section 34 of FICA stipulates that the FIC, after consulting an accountable institution, a reporting institution, or a person required to make a report in terms of sections 28 or 29 of FICA, has reasonable grounds to suspect that a transaction or a proposed transaction may involve the proceeds of unlawful activities or may constitute money laundering or may constitute a transaction contemplated in section 29(1)(b), then may direct that the transaction may not be proceeded with by the institution involved therein. ${ }^{10}$ The FIC prepared Guidance Note 4 to assist accountable institutions to meet their reporting obligations under FICA. ${ }^{111}$

Unfortunately FICA does not define "suspicion". ${ }^{112}$ A suspicious state of mind is subjective, which means the court would have to draw inferences concerning a person's state of mind in relation to a particular set of circumstances from the evidence at its disposal concerning those circumstances. ${ }^{113}$ However, FICA does add an element of objectivity with the phrase "ought reasonably to have known or suspected" in section 29 (1) of FICA". ${ }^{114}$ Therefore, the court would most probably embark on an analysis of the subjective and the objective in order to reach a value judgment.

\section{Comment}

Both FICA and POCA, place onerous and controversial mandatory reporting and disclosure duties on accountable institutions such as attorneys as well as on supervisory bodies. ${ }^{115}$ Attorneys have protested against such mandatory

106 Van der Westhuizen "Interpreting S 29 and the Obligation to Report" April 2004 De Rebus 37 38.

107 Ibid.

108 Du Plessis Re-interpretation of Statutes (2002) 103-104.

109 S 34 of FICA.

110 This, however, according to s 34(3) does not apply where the rules in terms of the Stock Exchanges Control Act 1985 or the Financial Markets Control Act 1989 apply.

111 FIC Guidance Note 4 on Suspicious Transaction Reporting 14 March 2008 5. Guidance provided from industry associations or other organization, does not have a bearing on assessing compliance with the obligations imposed by FICA or the interpretation of its provisions. FIC Guidance Note 46 . Furthermore, the guidance provided by the FIC in this regard, although authoritative, is provided as general information only. According to Guidance Note 4 , it is imperative that accountable institutions report their suspicion to the FIC. FIC Guidance Note 4 8. The Guidance Note also makes it clear that there is no mandatory threshold which applies to the reporting of suspicious or unusual transactions (FIC Guidance Note 4 17). The FICA Guideline: Financial Intelligence Centre Act, 20011 www.cape lawsoc.law.za (accessed 2012-10-24) is also worth mentioning. It was issued on behalf of the Cape Law Society for the sole purpose of assisting its members in the conduct of their practices, is not to be confused with the Guidance Notes issued by the FIC.

112 FIC Guidance Note 412.

113 FIC Guidance Note 413.

114 Ibid.

115 Bester "Money Laundering Legislation: Part 2, An 'Assault' on the Attorney-client Relationship and on the Independence of the Profession?" 2002 De Rebus 26. 
disclosure duties because such duties have a profound and deleterious impact on the independence of the Bar, which independence is crucial for the proper functioning of the administration of justice. ${ }^{16}$ Moreover, "a citizen's right to absolute confidentiality from [his] law firm is a basic fundamental legal right". Furthermore, the right to "absolute confidentiality", is completely disregarded in the money-laundering legislation. ${ }^{118}$ This is an argument which has spread across borders and is also applicable to South Africa. ${ }^{119}$ One has to agree that there is such a thing as absolute confidentiality and that attorneys should be trusted to deal with clients who may be involved with money-laundering activities by advising these clients of the illegality of their dealings and if necessary, by severing ties with these clients.

Unfortunately, the law does not see it like that and those who fail to report suspicious and unusual transactions are guilty of an offence in terms of section 52 of FICA. Section 68 of FICA stipulates that a contravention of section 52 of FICA renders a person "liable to imprisonment for a period not exceeding 15 years or to a fine not exceeding R10 000 000." The seriousness of the sanction necessitates detailed guidance by the law society in order to empower and protect their bona fide members. ${ }^{120}$ Failure to provide guidance, information and training will most likely have the result in rendering well-meaning attorneys accomplices in money-laundering schemes.

The reporting duties of any suspicious transactions create tension between the duties that attorneys have towards the state and those duties that are owing to their clients. ${ }^{121}$ In addition, attorneys effectively have to answer to the FIC, as well as to the LSSA.

$116 \mathrm{Ibid}$. Bester also refers to a joint statement on these mandatory reporting and disclosure duties which was issued by the presidents of various Bars of Australia, Germany, the Netherlands and Switzerland. This statement labels the mandatory reporting and disclosure duties as an aberration that "not even totalitarian dictators have asked [of] law firms".

117 Bester 2002 De Rebus 26; and as prescribed in s 97 of British Gazette 6.

118 Bester 2002 De Rebus 26.

119 A comparative analysis of the positions regarding the reporting duties that attorneys are faced with in both the United Kingdom and Canada as well as the approaches that they have taken respectively are discussed fully in par 72 and 73 below.

120 Burdette 2010 University of Pretoria research paper 2.

121 FICA imposes a number of other administrative obligations on accountable institutions, such as the formulation and implementation of internal rules, the appointment of a compliance officer and appropriate training regarding the combating of money laundering and terrorist financing, Burdette 2010 University of Pretoria research paper 22. S 31 of FICA is also of importance as it places additional reporting obligations on accountable institutions and states as follows: "If an accountable institution through electronic transfer sends money in excess of a prescribed amount out of the Republic or receives money in excess of a prescribed amount from outside the Republic on behalf, or on the instruction, of another person, it must, within the prescribed period after the money was transferred, report the transfer, together with the prescribed particulars concerning the transfer, to the Centre." A recent report which is published annually by the LSSA states that as from 4 October 2010, attorneys then have to report when payments exceeding such an amount are made in "cash". (Bekker "Financial Intelligence Centre Act committee" April 2011 to March 2012 The Law Society of South Africa Annual Report 36 36). "Cash" is defined in FICA as the following: "(a) coin and paper money of the Republic or of another country that are designated as legal tender and that circulate as, and are customarily used and accepted as, a medium of exchange in the country of issue; (b) traveller's cheques." The LSSA report notes that cash does not include negotiable instruments as defined in FICA, nor does it include a transfer of funds by means of bank cheque, bank draft, electronic funds transfer, wire transfer or other written order that does not involve the physical transfer of cash (Bekker April 2011 to March 2012 The Law Society of South Africa Annual Report 36). It is interesting to note that these methods of transferring funds will not be covered by the cash 


\section{$5 \quad$ ATTORNEYS' ETHICS AND PROFESSIONAL DUTIES}

\section{General}

It becomes incumbent to discuss legal professional privilege in some detail and to show how the the duty to report and other duties in terms of FICA conflict with and affect legal professional privilege. Both the rules of confidentiality and legal professional privilege stem from what legal practitioners know as professional conduct or ethics which is as much part of the law as any other. ${ }^{122}$ Professional ethics refer to a body of rules drawn from various sources, which regulate the conduct within the legal profession. ${ }^{123}$

According to Lewis's golden rule, a practitioner must avoid all conduct, which, if known, could damage his reputation as an honourable lawyer and an honourable citizen. ${ }^{124}$ A failure to act in accordance with these rules is sanctioned through disciplinary steps that may include the suspension or removal from the roll of practitioners. ${ }^{125}$ Legal practitioners have duties, not only towards their clients, but also towards the state, ${ }^{126}$ the court, ${ }^{127}$ their colleagues, correspondents, advocates, witnesses in both civil and criminal matters, the provincial Law Societies, and the public. It is, however, their duties towards their clients that form the subject of the present discussion.

threshold reporting obligation under $s 28$ of FICA whereas physical cash payments presented to and received by an attorney are covered Also, the situation where an attorney who makes a payout to a client consisting of physical cash, will also be covered. Practitioners have been asked by the LSSA that they were obliged to report not only any suspicious transactions but also payments in excess of twenty-five thousand Rands. The LSSA has urged attorneys to register with the FIC as accountable institutions, and to comply with FICA, as well as complying with a set of internal rules which have been circulated electronically by the LSSA and which are available on the LSSA website (www.lssa.org.za (accessed 2012-10-24)).

122 Lewis Legal Ethics: A Guide to Professional Conduct for South African Attorneys (1982) 3.

${ }^{123}$ Bodenstein, Boniface, De Klerk, Hope, Kok, Mahomed, Steenhuizen, Stilwell, and Wimpey Clinical Law in South Africa (2004) 34.

124 Hoffmann Legal Education And Development, Law Society of South Africa Professional Conduct 6.

125 Bodenstein et al Clinical Law in South Africa 34.

126 With regards to a practitioner and his relationship with the state, he has a duty to uphold the law and to follow all legal channels (Hoffmann Legal Education And Development, Law Society of South Africa Professional Conduct 43). In the matter of the Society of Advocates of South Africa (Witwatersrand Division) v Fischer 1966 (1) SA 133 (T) 137F, De Wet JP stated the following: "it is the duty of an attorney to further the administration of justice in accordance with the laws of the country and not frustrate it ..." and 137D, "it is the court's duty to uphold and enforce the laws of the country .... it would be inconsistent with that duty for the court to allow an advocate to remain on when he is defying these laws and instigates other so defying these laws".

127 With regards to an attorney's relationship with the court, legal practitioners occupy a unique position. On one hand, they serve the interests of their clients, which require a case to be presented fearlessly and vigorously On the other hand, legal practitioners are officers of the court who serve the interests of justice itself by acting as a bulwark against the admission of fabricated evidence. Legal professionals have strict ethical rules aimed at preventing their members from becoming parties to the deception of the court. With the preservation of a high standard of professional ethics which is left almost entirely in the hands of individual practitioners, it stands to reason that absolute professional integrity and scrupulous honesty are demanded of practitioners (Hoffmann Legal Education And Development, Law Society of South Africa Professional Conduct 6). 
The attorney and client relationship is based on a contract of mandate. ${ }^{128}$ There is an implied term of contract between an attorney and his/her client that the attorney will preserve the confidentiality of all communications, whether oral or documentary, between the attorney and his/her client. ${ }^{129}$ Unless granted absolute assurance of confidentiality, clients will be reluctant to disclose all material facts to their legal representatives, which in turn may prejudice the client's case. ${ }^{130}$ The confidence of the client must be preserved by his attorney except to the extent that disclosure may be rendered necessary or permissible. ${ }^{131}$ It embraces all oral and documentary information respecting the client's affairs gained in acting for him whether from the client himself or from any other source whatsoever. ${ }^{32}$

The concept of confidentiality is wider than that of privilege, since information may be confidential even though it is not protected by legal professional privilege. ${ }^{133} \mathrm{~A}$ duty of confidentiality exists when a party has a right to prevent another from disclosing confidential information to someone else. ${ }^{134}$ Thus the duty of confidentiality may arise from either a contract or a delict and a breach of this duty may result in an action for damages, or the granting of an interdict against further disclosure. ${ }^{135}$

Compliance with section 29 of FICA may have the effect of compromising the confidential relationship between an attorney and his client. ${ }^{136}$ Remember, section 37 of FICA holds that the reporting obligations override any duty of secrecy or confidentiality imposed by legislation, agreement or the common

${ }^{128}$ Incorporated Law Society Transvaal v Meyer 1981 (3) SA 962 (T) 970. A contract of mandate is an agreement between a principal and an agent.

129 Hoffmann Legal Education And Development, Law Society of South Africa Professional Conduct 26; and Bodenstein et al Clinical Law in South Africa 34.

130 Bodenstein et al Clinical Law in South Africa 34. It is impractical to expect an attorney to act in the best interests of his client if certain important information which the case may hinge upon, is not divulged by the client. Wessels JA (as he then was) remarked on this point in Robinson $v$ Hulsteyn Feltham \& Ford 1925 AD 12 "a client is often compelled to reveal to his solicitor the most intimate circumstances in his life. The solicitor may thus become the repository of the most vital secrets. The confidences reposed in him he may not divulge, and if he does, the Court will punish him for his breach of duty towards his client."

131 Lewis Legal Ethics: A Guide to Professional Conduct for South African Attorneys 291; and Hoffmann Legal Education And Development, Law Society of South Africa Professional Conduct 26.

132 Ibid. The information covered by the ethical duty of confidentiality must be regarded as confidential by the client and lawyers are advised, according to Hoffmann, that if in doubt, to regard even matters that are generally known, eg, the client's name, address, job and marital status and even the fact that he or she has retained the lawyer's service, as confidential, unless the client advises the legal practitioner to the contrary. For instance, if an attorney is asked to provide the client's address, the attorney should decline to do so unless he knows that the client does not regard his/her address as confidential (Hoffmann Legal Education And Development, Law Society of South Africa Professional Conduct 27). A simple act of revealing a client's whereabouts to a third party without permission to do so can amount to a breach in confidentiality and as such may constitute professional misconduct (Hoffmann Legal Education And Development, Law Society of South Africa Professional Conduct 217).

${ }_{133}$ Bodenstein et al Clinical Law in South Africa 34.

134 Ibid.

135 Ibid. What this means in practice is that a practitioner must at all times preserve the confidentiality of the client's affairs. Confidentiality continues to remain in existence even after the termination of the attorney-client relationship and can only be waived by the client. See also Hoffmann Legal Education And Development, Law Society of South Africa Professional Conduct 27.

136 Van der Westhuizen "Attorneys, Privilege and Confidentiality" June 2004 De Rebus 3737. 
law. ${ }^{137}$ However, if section 37(2) is taken into account, the reporting obligations under FICA do not apply to communications that are protected by legal professional privilege ${ }^{138}$ and thus do not override the common-law rules of legal professional privilege. ${ }^{139}$ It is therefore essential to distinguish between confidentiality and privilege. ${ }^{140}$ Confidentiality is a wider concept than privilege, since information may be confidential even though it is not protected by legal professional privilege. ${ }^{141}$ Confidentiality is a necessary condition for claiming privilege but it is not a sufficient condition for such a claim. ${ }^{142}$ The mere fact that a communication was made in confidence will not necessarily mean that that communication is privileged. ${ }^{143}$ That privilege attaches only if the communication is made for the purpose of obtaining legal advice, so that a statement, unconnected with the giving of legal advice, will not be privileged even if it was made in confidence.

In addition to the contractual obligation of confidentiality, there exists a doctrine in our law that confidential communications between an attorney and his client are "privileged" from disclosure. ${ }^{145}$ Attorneys may therefore be obliged to disclose confidential communications between attorney and client but not information subject to attorney and client privilege in terms of section 37(2) of FICA. ${ }^{166}$ The law of professional privilege applicable in South Africa is as it was in the English law on 30 May 1961. ${ }^{97}$ The general rule in our law is that communications between a legal adviser and his or her client are privileged if the legal adviser was acting in a professional capacity at the time, the adviser was consulted in confidence, ${ }^{148}$ the communication was made for the purpose of obtaining legal advice and the advice does not facilitate the commission of a crime or fraud. ${ }^{49}$

137 This section provides as follows: "(1) Subject to subsection (2), no duty of secrecy or confidentiality or any other restriction on the disclosure of information, whether imposed by legislation or arising from the common law or agreement, affects compliance by an accountable institution, supervisory body, reporting institution, the South African Revenue Service or any other person with a provision of this Part."

138 Van der Westhuizen June 2004 De Rebus 37.

139 Adv Trengrove legal opinion 2002118 (unpublished). S 37(2) of FICA stipulates: "Subsection (1) does not apply to the common-law right to legal professional privilege as between an attorney and the attorney's client in respect of communications made in confidence between (a) the attorney and the attorney's client for the purposes of legal advice or litigation which is pending or contemplated or which has commenced; or (b) a third party and an attorney for the purposes of litigation which is pending or contemplated or has commenced."

140 It is also of the utmost importance that practitioners are fully conversant with the precise nature and scope of professional privilege, and of confidentiality, and most importantly with the distinction between the two as well as the differing protection afforded to each in law (Hoffmann Legal Education And Development, Law Society of South Africa Professional Conduct 27).

141 Van der Westhuizen June 2004 De Rebus 37.

142 Ibid.

143 Ibid

144 Ibid.

145 Hoffmann Legal Education And Development, Law Society of South Africa Professional Conduct 27.

146 Ibid. See FIC Guidance Note 419.

147 Schmidt and Zeffert "Evidence" in Joubert and Faris (eds) The Law of South Africa Vol 2 (2005) 503 par 754.

148 Bank of Lisbon and South Africa Limited v Tandrien Beleggings (Pty) Ltd 1983 (2) SA 626 (W).

149 Zeffertt and Paizes The South African Law of Evidence (2009) 625; and Schmidt and Zeffert in Joubert and Faris (eds) The Law of South Africa Vol 2503 par 754. 
With regard to a legal advisor acting in his professional capacity, the mere fact that a person is an advocate or an attorney doesn't necessarily mean that everything that the attorney or advocate might say, or might be said to him for the purpose of obtaining his or her advice will be privileged. ${ }^{150} \mathrm{~A}$ relationship between legal adviser and client must, however, exist for communication to be regarded as privileged, and advice should not be given on a friendly basis only, as friendly conversation will not be covered in terms of privilege. ${ }^{15}$

Legal professional privilege means that communications between a legal practitioner and a client may not be used in evidence. ${ }^{152}$ Put differently, it is the protection from evidential use of certain confidential material. ${ }^{153} \mathrm{~A}$ client has a fundamental right to give and take legal advice with complete confidence that communications between legal practitioner and client are protected. ${ }^{154}$ Without such right our adversarial system of litigation cannot operate properly. ${ }^{15}$ Section 201 of the Criminal Procedure Act ${ }^{156}$ makes provision for privilege of a legal practitioner in criminal proceedings. ${ }^{157}$ The privilege is the privilege of the client, not the attorney and if an attorney claims privilege, he does so on behalf of the client. In fact, the attorney has a duty to claim such privilege. ${ }^{158}$ Privilege does not operate if the client obtains the legal advice in order to further a criminal end. ${ }^{159} \mathrm{~A}$ legal advisor who knowingly participates in the commission of a crime does not act professionally and the authorities suggest that even if he had no knowledge of the purpose for which advice was sought, no privilege will attach to the communications with the client if the latter obtained the advice in order to further a criminal objective. ${ }^{160}$

The doctrine of legal professional privilege is not a mere rule of evidence, it is necessary for the proper functioning of the legal system. ${ }^{161}$ This point cannot

150 Burdette 2010 University of Pretoria research paper 31; and Schmidt and Zeffert in Joubert and Faris (eds) The Law of South Africa Vol 2503 par 754

151 Burdette 2010 University of Pretoria research paper 31.

152 Bodenstein et al Clinical Law in South Africa 34.

153 Hoffmann Legal Education And Development, Law Society of South Africa Professional Conduct 27.

154 Ibid.

155 Ibid.

15651 of 1977.

157 "No legal practitioner qualified to practise in any court, whether within the Republic or elsewhere, shall be competent, without the consent of the person concerned, to give evidence at criminal proceedings against any person by whom he is professionally employed or consulted as to any fact, matter or thing with regard to such practitioner would not on the thirtieth day of May,1961, by reason of such employment or consultation, have been competent to give evidence without such consent: Provided that such legal practitioner shall be competent and compellable to give evidence as to any fact, matter or thing which relates to or is connected with the commission of any offence with which the person by whom that legal practitioner is professionally employed or consulted, is charged, if such fact, matter or thing came to the knowledge of such legal practitioner before he was professionally employed or consulted with reference to the defence of the person concerned."

158 Van der Westhuizen June 2004 De Rebus 37.

159 Ibid.

160 Ibid. Schmidt and Rademeyer Law of Evidence (2011) 20-26 note that the court has a duty to ensure that this fundamental right is protected, and if it is not effectively protected, it may hamper the legal system since clients will then naturally be less inclined to communicate honestly and openly with their legal advisors.

161 Hoffmann Legal Education And Development, Law Society of South Africa Professional Conduct 27. 
be overemphasized. ${ }^{162}$ One cannot agree more with this point of view: Sufficient trust in the attorneys' integrity and ethical behaviour in circumstances where clients engage in illegal activities should be sufficient. ${ }^{163}$

There are many opinions regarding the attorneys' reporting duties in terms of FICA and legal professional privilege. Trengrove mentions that, even though privilege and confidentiality are separate concepts, these overlap since confidentiality is a "necessary condition but not a sufficient condition of legal professional privilege". ${ }^{164}$ Furthermore, communication must be intended to be confidential in order for it to be privileged. ${ }^{165}$ The connection between confidentiality and legal professional privilege has been explained in the matter of Bank of Lisbon and South Africa Ltd v Tandrien Beleggings (Pty) Ltd ${ }^{166}$ as "the basis of privilege is confidentially. When confidence ceases, privilege ceases". ${ }^{17}$ One can agree with this statement.

Problems arise when communications that were made in confidence between attorneys and clients that are unrelated to the giving of legal advice referred to as non-privileged confidential information. Section 37(1) overrides

162 Schmidt and Zeffert in Joubert and Faris (eds) The Law of South Africa Vol 2503 are of the same view as Schmidt and Rademeyer, in that legal professional privilege is seen as a right necessary for the proper functioning of the adversarial system. It is considered to be in the best interest of the administration of justice that there should be full and frank disclosures between clients and their legal advisers which support a relationship of open communication. The rationale behind the privilege is therefore not to be seen as keeping communications confidential, but rather to be understood in the context of aiding litigation which is in the public interest. As a corollary to the proposition that privilege is conceived as an aid to litigation, and the interests of the public, the privilege is the client's and not the lawyer's. See also Burdette 2010 University of Pretoria research paper 25.

163 S v Safatsa 1988 (1) SA 868 (AD) 886E, regards privilege as a "doctrine which was based upon the view that confidentiality was necessary for the proper functioning of the legal system and not merely the proper conduct of particular litigation". The court concluded that a claim proposing to relax privilege must be approached with great circumspection. An accused's right to legal professional privilege can also be noted from the rights that accused persons in criminal matters are entitled to according to the Constitution, such as the right to effective legal representation as well as the right to a fair public hearing (s 36) coupled with substantive fairness (see Burdette 2010 University of Pretoria research paper 26). However, in the Constitutional Court matter of Thint (Pty) Ltd v NDPP; Zuma v NDPP (2008) 2 SACR 421 (CC) the court accepted that the right to privilege is not an absolute right, and that it could be outweighed, in appropriate cases by countervailing considerations. Some authors are of the view that fair administration of justice can be impaired as a result of the privilege and therefore the ambit of the privilege needs to be limited (Burdette 2010 University of Pretoria research paper 26).

164 Adv Trengrove legal opinion 2002 (unpublished) (see fn 139 above) 15.

165 Adv Trengrove legal opinion 2002 (unpublished) (see fn 139 above) 15, notes with reference to the matter of Geovagnoli v Di Meo 19603 SA 393 (D) 399 A-B that it is a question of fact whether communication was made in confidence.

1661983 (2) SA 262 (W) 629G.

167 Adv Trengrove legal opinion 2002 (unpublished) (see fn 139 above) 15, interprets s 37 of FICA is as follows: "Section $37(1)$ deals with confidentiality whilst section $37(2)$ deals with privilege. Section 37(1) provides that reporting obligations in terms of FICA override 'any duty of secrecy or confidentiality or any other restriction in the disclosure of information' irrespective of whether the restriction is imposed by legislation, or common law or an agreement. The operation of section $37(1)$ is subject however to section $37(2){ }^{167}$ This provides that section $37(1)$ does not apply to communications that are protected by common-law rules of legal professional privilege whilst section $37(2)$ privilege extends to communications made in confidence between an attorney and client for either the purposes of legal advice or actual or contemplated litigation, or an attorney or third party for the purposes of legal advice or actual or contemplated litigation." 
the duty of confidentiality that falls short of legal professional privilege. ${ }^{168}$ Trengrove argues that there is a need for attorneys to be able to distinguish between information falling within section 37(1) and 37(2) of FICA, which may invariably give rise to difficulties in practice that may represent "a significant burden to the attorney". ${ }^{169}$ It is difficult to distinguish between information or communications which may be confidential and thus reportable under section $37(1)$ of FICA, and communications which are privileged and protected by section 37(2) of FICA.

A very relevant matter is the constitutionality of section $37(1)$ of FICA Trengrove analysed in detail various rights of the Constitution against the reporting obligation such as the right to privacy, ${ }^{170}$ a fair criminal trial, ${ }_{171}^{171}$ a fair public hearing, ${ }^{172}$ a trade, ${ }^{173}$ freedom and security of the person, ${ }^{174}$ and concluded that the Constitution is not violated in this regard. ${ }^{175}$ With regard to section 14 of the Bill of Rights the fundamental right to privacy is protected and it includes the right not to have, inter alia, the privacy of their communications infringed. ${ }^{176}$ Although FICA probably infringes this right to privacy by requiring attorneys to disclose non-privileged confidential information, ${ }^{177}$ the question is whether such an infringement is justified in terms of section 36(1) of the Constitution. Given the purpose of FICA as a whole, the state probably has a legitimate interest in requiring the disclosure of the confidential information that does not satisfy the requirements of privilege (non-privileged confidential information). ${ }^{178}$ FICA accordingly does not violate the right to privacy. ${ }^{179}$ Rather, the provisions of the FICA that require attorneys to disclose nonprivileged confidential information are rationally connected to a legitimate government purpose, and the fact that the legislature might have achieved its end by less restrictive means does not render those provisions "irrational". ${ }^{180}$

Whether FICA destroys the independence of the attorneys' profession and whether section 37 of FICA is 'irreconcilable with the notion of attorney-client confidentiality' was answered in light of section 1(d) which states that the Republic of South Africa is founded on the values of the "rule of law" as well as section 35(3)(f) of the Constitution which states that an accused person has the right "to choose, and to be represented by a legal practitioner". ${ }^{18}$

Trengrove supports the notion that FICA does not override attorney-client privilege. In fact, it protects privileged information in section 37(2) of FICA, and

\footnotetext{
168 Ibid.

169 Adv Trengrove legal opinion 2002 (unpublished) (see fn 139 above) 23.

$170 \mathrm{~S} 14$ of the Constitution, 1996.

$171 \mathrm{~S} 35$ of the Constitution, 1996.

172 S 34 of the Constitution, 1996.

173 S 22 of the Constitution, 1996.

$174 \mathrm{~S} 12(1)$ of the Constitution, 1996.

175 Adv Trengrove legal opinion 2002 (unpublished) (see fn 139 above) 24-36 for a detailed discussion.

176 S 14(d) of the Constitution, 1996.

177 Adv Trengrove legal opinion 2002 (unpublished) (see fn 139 above) 27.

178 Ibid.

179 lbid.

180 Adv Trengrove legal opinion 2002 (unpublished) (see fn 139 above) 37. See also New National Party of South Africa v Government of the Republic of South Africa 1999 (3) SA 191 (CC) par 24.

181 Adv Trengrove legal opinion 2002 (unpublished) (see fn 139 above) 38.
} 
it is only non-privileged confidential information that section $37(1)$ of FICA requires reporting by attorneys. ${ }^{182}$ Thus, the enforced disclosure of nonprivileged confidential information does not threaten the existence of the independent legal profession. ${ }^{183}$ The writer concludes that section 37(2) of FICA recognizes and protects legal professional privilege. ${ }^{184}$ Furthermore attorneys have never had an entitlement to refuse to disclose to court nonprivileged confidential information regarding a client and that this has not inhibited the growth of an independent attorney's profession. ${ }^{185}$ This reporting obligation directly impacts on attorneys as it places a reporting obligation on them to report suspicious and unusual transactions, which are not subject to legal professional privilege. ${ }^{186}$ The attorney's relationship with a client is, however, always understood and practised in the context of client confidentiality or the legal professional privilege, which results in discomfort regarding this reporting obligation. ${ }^{187}$

If not unconstitutional, section 37 of FICA may still be seen as harsh and the demands of FICA extraordinary. ${ }^{188}$ According to the LSSA guidelines, ${ }^{189}$ the provisions of FICA do not impact on an attorney's ethical right and duty not to accept an unlawful mandate from a client or to withdraw from a matter. ${ }^{190}$ Similarly, there is also no requirement in FICA that prescribes that an attorney must cease working for a client where a report has been made to the FIC, particularly where the matter reported is relatively trivial. ${ }^{191}$ Van der Westhuizen, however, suggests that it would be preferable to discontinue the professional attorney-and-client relationship as soon as possible before a report is made in terms of sections 29(3) and (4) of FICA, given the risk that continuing to act for a client might constitute a money-laundering offence. ${ }^{192}$ It is further advised in this respect that care should be taken to ensure that an attorney's withdrawal from a matter cannot be construed in any way as tippingoff the client. ${ }^{193}$

Bester is of the opinion that the mere notion of the "conscription" of attorneys to "spy" on and report the doings of their unsuspecting clients to a government agency and to be designated the repository of the client's rights, no matter how noble the cause, is morally and ethically repugnant. ${ }^{194}$ Perhaps, the suggestion

\footnotetext{
182 Adv Trengrove legal opinion 2002 (unpublished) (see fn 139 above) 39.

$183 \mathrm{Ibid}$. Trengrove thus summarizes that the rules of privilege rather than confidentiality are essential for the existence of the legal profession. If the rules of privilege and confidentiality are inextricably linked then there may be specific circumstances where the constitutional rights are infringed. It needs to be determined on a case by case basis, however, especially given the fact that constitutional rights are interdependent and interrelated.

184 Adv Trengrove legal opinion 2002 (unpublished) (see fn 139 above) 41.

185 Ibid.

186 Burdette 2010 University of Pretoria research paper 2.

187 Ibid.

188 Ibid

189 The guidelines endorsed by the LSSA should not be confused with the "guidance notes" referred to in the regulations to FICA; and S 4(c) of FICA imposes an obligation on the FIC to give guidance to accountable institutions, supervisory bodies and other persons regarding the performance by them of their duties and their compliance with the provisions of FICA.

190 Van der Westhuizen July 2004 De Rebus 34.

191 Ibid.

192 Ibid.

193 Ibid.

194 Bester 2002 De Rebus 29.
} 
in respectful retort to Trengrove's findings, that the issue has to be dealt with on a case-by-case basis, bears more significance in light of the issues raised by the learned authors in this section.

\section{INTERNATIONAL BAR ASSOCIATION}

The International Bar Association ("IBA") published the International Bar Principles on Conduct for the Legal Profession, ${ }^{195}$ which was developed for practising lawyers across the globe, and which provides lawyers with a framework to carry out their professional duties in a manner consistent with upholding the dignity and respect the profession in relation to their clients. ${ }^{196}$

The gathering pace of globalization and increase in cross-border transactions has led to the Code of Ethics being revisited and republished, resulting in the most recent publication. ${ }^{197}$ The Commentary on the International Bar Association's International Principles on Conduct for the Legal Profession was adopted by the International Bar Association at the Warsaw Council Meeting on 28 May 2011.

Article 4 of the IBA Principles deals with confidentiality and professional secrecy and states that the general principle is that: "A lawyer shall at all times maintain and be afforded protection of confidentiality regarding the affairs of present or former clients, unless otherwise allowed or required by law and/or applicable rules of professional conduct."

Furthermore, the explanatory note to the general principle in Article 4 above emphasizes the right and duty of a lawyer to keep information received from and advice given to clients confidential as it is not only an indispensable feature of the rule of law. ${ }^{198}$ It is also essential to public trust and confidence in the administration of justice as well as the independence of the legal profession. ${ }^{199}$

The IBA principles recognize, however, that recent legislation imposing special duties upon lawyers to assist in the prevention of criminal phenomena such as terrorism, money laundering or organized crime has further eroded the protection of the lawyer's duty of confidentiality. ${ }^{200}$

The lawyer's obligation of confidentiality and professional secrecy according to the IBA principles applies also to assistants, interns and all employed within the law firm. ${ }^{201}$ Furthermore, the IBA principles advise that lawyers should also take care to ensure that confidentiality and professional secrecy are maintained in respect of electronic communications, and data stored on computers. ${ }^{202}$

\footnotetext{
195 See http://www.ibanet.org/Article /Detail.aspx (accessed 2012-10-24).

196 Ibid.

197 Ibid

198 Ibid.

199 Ibid.

200 Ibid. Many bars are opposed to this legislation and any encroachment on the lawyer's duty should be limited to information that is absolutely indispensable to enable lawyers to comply with their legal obligations or to prevent lawyers from being unknowingly abused by criminals to assist their improper goals. If neither of the above is the case and a suspect of a past crime seeks advice from a lawyer, the duty of confidentiality should be fully protected.

201 Ibid.

202 Ibid.
} 
Even though both the guidelines and the IBA principles recognise the importance of confidentiality and privilege in the legal profession, they like FICA, are prepared to overlook confidential communications in situations where the information is "absolutely indispensable" in order to allow attorneys to help combat money laundering. This doesn't help alleviate the tension and uncertainty, however, as what is considered "absolutely indispensable" can only be determined on a case-by-case basis.

\section{INTERNATIONAL MONEY-LAUNDERING INSTRU- MENTS AND COMPARATIVE ANALYSIS OF MONEY- LAUNDERING PROVISIONS AND REPORTING OBLIGATIONS}

\section{International instruments and standards}

With a view to encouraging co-operation and mutual legal assistance and creating a minimum international standard in money-laundering and drugtrafficking counter-measures, a number of countries became signatory to various international regulatory and policy instruments. ${ }^{203}$ These include the Vienna Convention, ${ }^{204}$ the 1999 United Nations International Convention for the Suppression of the Financing of Terrorism, ${ }^{205}$ United Nations convention Against Transnational Organized Crime 2003 (the Palermo Convention) ${ }^{206}$ and the United Nations Convention Against Corruption. ${ }^{207}$ With the signing of international instruments such as the Vienna and Palermo Conventions, South Africa confirmed its commitment towards the combating of crime and money laundering. ${ }^{208}$ Another indication of this commitment is South Africa's joining the FATF in 2003 which is an inter-governmental body that focuses exclusively

Ibid.

204 http://www.unodc.org/pdf/convention 1988 en.pdf (accessed 2012-10-24); and South Africa acceded to this Convention on 14 December 1998. 1988 United Nations Convention against Illicit Traffic and Narcotic Drugs and Psychotic Substances the foundation of the international legal anti-money laundering regime" that could be similarly regarded in relation to the South African anti-laundering initiative (Van Jaarsveld 2006 Obiter 240). This Convention requires signatory states to criminalise laundering acts in relation to proceeds of drug offences by persons who know that the proceeds were derived from drug offences (De Koker KPMG South African Money Laundering and Terror Financing Law com 10).

205 This convention came into force in October 2002 and requires signatory states to criminalize the financing of terrorist acts to allow for the detection, freezing and confiscation of such funds (De Koker KPMG South African Money Laundering and Terror Financing Law com 10).

206 South Africa ratified this convention on 20 February 2004.

207 This convention that has been ratified by 20 African countries, requires that states establish mechanisms to review suspicious transactions, analyse financial data and exchange information (Moshi 2007 Institute for Security Studies 40. This Convention also requires signatory states to take specific steps to prevent corruption, to criminalize certain corrupt acts, to combat money laundering and to render international assistance to other countries wishing to combat corruption, especially in relation to asset recovery (De Koker KPMG South African Money Laundering and Terror Financing Law com 10).

208 Burdette 2010 University of Pretoria research paper 1; See also Guideline: Financial Intelligence Centre Act, 20011 www.capelawsoc.law.za (accessed 2012-10-24) 2, where it is noted that South Africa became a signatory to the Palermo Convention in December 2000 and this has triggered the introduction of domestic legislation to combat and deter money laundering. The FAFT was established by the G-7 Summit in Paris in July 1989 to examine measures to combat money laundering http://www.fatf-gafi.org (accessed 2012-10-02). 
on combating money laundering and funding of terrorism. ${ }^{209}$ The FATF is essentially a policy-making and standard-setting body that promotes policies to combat money laundering. ${ }^{210}$ In 1990, the FATF formulated the so-called Forty Recommendations to address the problem ${ }^{211}$ These recommendations which have been reviewed in 2012 are "soft law.",212

The financial provisions of the Recommendations mirror the general "knowyour-client" policy provisions and relate to both banks and non-bank institutions. ${ }^{213}$ Included are recommendations concerning the elimination of anonymous accounts; record keeping; suspicious transactions reporting; and encouragement of modern systems of money management in the lieu of the cash practices. ${ }^{214}$

The implementation of the Recommendations by members and nonmembers is essentially enforced through peer political and economic pressure. ${ }^{215}$ Recommendation 23(a) states that: "Lawyers, notaries, other independent legal professionals and accountants should be required to report suspicious transactions when, on behalf of or for a client, they engage in a financial transaction in relation to the activities described in paragraph (d) of Recommendation 22."216 This particular recommendation is the culmination of several years of hard work by the IBA Anti-Money Laundering Legislation Implementation Group ("AMLLIG"), the American Bar Association and the

209 De Koker KPMG South African Money Laundering and Terror Financing Law com 12.

210 De Koker KPMG South African Money Laundering and Terror Financing Law com 13.

211 Ibid; and the Recommendations were accepted by the G-7 Summit in Houston in July 1990. The Forty Recommendations were revised for the first time in 1996 and again in 2003 so as to take into account changes in money-laundering methods, techniques and trends. The current membership of the FATF comprises of 34 governments and two regional organizations being the European Commission and the Gulf Co-operation Council.

212 Bachus "From Drugs to Terrorism: The Focus Shifts in the International Fight Against Money Laundering after September 11, 2001" 2004 Arizona Journal of International and Comparative Law 835 851. The FATF made a "deliberate choice not to cast the recommendations into the mould of a treaty" for two reasons: to avoid a time-consuming and extensive ratification process and to provide for flexible adaptation of the Recommendations by member countries. The non-binding status of the Forty Recommendations has been called into question, however, because of the FATF's actions with respect to countries and jurisdictions deemed by the FATF to have failed to comply with the Forty Recommendations which all FATF members are expected to adopt.

213 Van Jaarsveld 2006 Obiter 239.

$214 \mathrm{lbid}$. In essence the functions of the FATF are the monitoring of the progress that members make in implementing measures to combat money laundering and financing of terrorism, the reviewing techniques to launder money and finance terrorism and considering countermeasures globally promoting the adoption and implementation of measures to combat money laundering and financing of terrorism. See De Koker KPMG South African Money Laundering and Terror Financing Law com 14.

215 Ibid. Recommendation 22(d) (Designated non-financial business and profession: customer due diligence and record-keeping requirements) apply to lawyers, notaries, other independent legal professionals and accountants. These recommendations apply to these professionals when they prepare for or carry out transactions for their client concerning the buying and selling of real estate. It also applies when managing client money, securities or other assets, bank, savings or securities accounts. The recommendations further apply when these individuals organize contributions for the creation, operation or management of companies and the creation, operation or management of legal persons or arrangements, and buying and selling of business entities. See International Standards on Combating Money Laundering and the Financing of Terrorism \& Proliferation The FATF Recommendations (February 2012) 20 ${ }^{216}$ Ibid. www.fatf.gafi.org (accessed 2013-04-22) 
Council of Bars and the Law Societies of Europe. These organizations have have worked intensively to move the FATF from a position of knowing little and caring less about the unique nature of the legal profession to one where there is now a proper dialogue. ${ }^{217}$

There are therefore global standards and guidelines on reporting duties, and FICA is clearly not a local weapon of terror. In order to elaborate on this statement, country-specific discussions of Canada and the United Kingdom will now be provided.

\section{Canada}

\section{General}

Within the Canadian federal democracy, provincial legislators are responsible for legislation governing the legal profession. ${ }^{218}$ The Federation of Law Societies of Canada ("the Federation") is the coordinating body of the 14 governing bodies that are statutorily charged with the responsibility of governing Canada's lawyers in the public interest. ${ }^{219}$ The Federation, on behalf of its member law societies, has publicly stated its support for the Canadian government's efforts to fight money laundering and terrorist financing, recognizing the importance of the objectives of federal legislation and concurring with its basic purpose. ${ }^{220}$

The Canadian anti-money-laundering framework is contained in the Proceeds of Crime (Money Laundering) Act, ${ }^{221}$ ("PCMLA") and related regulations. ${ }^{222}$ These provisions loosely follow the Criminal Justice Act 1993 ("CJA") provisions of the United Kingdom which is the second foreign law country this paper focuses on. ${ }^{223}$ The PCMLA encompasses the proceeds of a "designated offence" in Canada or an offence committed elsewhere which would constitute a "designated offence" had it been committed in Canada. ${ }^{224}$

The PCMLA which was enacted by the federal government in 2000 in response to the original FATF 40 Recommendations and its regulations, seek to tighten the trade practices which make a particular industry or profession

217 Rose "Making the Case for Appropriate Anti-money Laundering Rules for Lawyers" 2009 International Bar News 37 37; and the AMLLIG has been clear that it strongly supports the fight against money laundering, but equally it questions whether lawyers should be quite the target they have been. Lawyers have been fighting for their own rules with regards to anti-moneylaundering provisions.

218 MacDonald "Money Laundering Regulation - What Can be Learned from the Canadian Experience" 2012 Journal of the Professional Lawyer 143143.

219 Ibid.

220 Ibid.

221 2000c 17

222 Bennett $A$ Practitioner's Guide to Money Laundering Compliance (2004) 80.

223 Ibid.

224 Ibid. Other Canadian anti-money-laundering laws and regulations include the Proceeds of Crime (Money Laundering) Suspicious Transaction Reporting Regulations, Proceeds of Crime (Money Laundering) and Terrorist Financing Act 2001, and the Proceeds of Crime (Money Laundering) and Terrorist Financing Regulations (Bennett $A$ Practitioner's Guide to Money Laundering Compliance 81). 
vulnerable to money-laundering activities. ${ }^{225}$ Under the scope of the Terrorist Financing Act 2001 regulated persons and entities are required to report "suspicious transactions" and certain other financial transactions to the Financial Transactions and Reports Analysis Centre of Canada, a federal agency that was set up to receive and analyse financial intelligence and disclose it to the police. ${ }^{226}$ The Canadian legal profession viewed the provisions of the legislation and proposed regulations affecting legal counsel as infringing on solicitor-client confidentiality and the fundamental independence of Canadian lawyers.

South African anti-money-laundering legislation is similar to that of Canada in that both countries have enacted modern legislation which is particularly onerous on attorneys. Both countries have their own respective law societies that regulate the legal profession. ${ }^{28}$

\section{The legal profession and money laundering}

Initiatives to fight money laundering, which include the fulfilment of Canada's commitments through its membership in the FATF, must be accomplished within the framework of Canadian societal values and constitutional principles. ${ }^{229}$ The FATF recognized such principles with, for example, Recommendation 16 (now 22d) which states that lawyers are not required to report suspicious transactions if the information was obtained in circumstances where they are subject to professional secrecy or professional privilege. ${ }^{230}$

\section{Lawyers' duties towards their clients}

There are different perspectives on lawyers' duties towards their clients. Justice Allan accepts that the "solicitor-client relationship" is a unique one, not comparable to the other professions and entities covered by the Act and Regulation.

225 Paton "Cooperation, Co-option or Coercion? The FATF Lawyer Guidance and Regulation of the Legal Profession" 2010 Journal of the Professional Lawyer 165172.

226 MacDonald 2012 Journal of the Professional Lawyer 144.

227 Paton 2010 Journal of the Professional Lawyer 172.

228 The reader must bear in mind that Quebec is the only province of Canada that has a different legal system to the rest of Canada, being governed by the French civil code and does not follow the common law. Solicitor-client privilege in Quebec falls under the more general rubric of "professional secrecy" and is rooted in s 9 of Quebec's Charter of Human Rights and Freedoms.

229 German Proceeds of Crime: The Criminal Law, Related Studies, Regulations and Agreements (1999) com 1-2.

230 lbid.

2312001 B.C.J No 2420 (BCSC) par 77 as referred to in Paton 2010 Journal of the Professional Lawyer 180. Chief Justice Kennedy noted the following in the matter of Federation of Law Societies of Canada v Canada (Attorney General) 2002 NSJ No1999 (NSSC) par 76-77 (as referred to in Paton 2010 Journal of the Professional Lawyer 180) states: "The functions of legal counsel are at the heart of the constitutionally protected principles of fundamental justice. The rule of law, the right to counsel, the right to remain silent, the privilege against self incrimination and the right to a fair trial, that is the broader public interest that they say they represent. The proper functions of legal counsel sustain and allow for the constitutionally entrenched principles that are so significant to the maintenance of the rule of law." 
Lawyers are required to report the activities of their clients to the government in disregard of the Code of Professional Conduct, which "generally requires lawyers to hold in strict confidence all information concerning the business and affairs of clients." ${ }^{232}$

Paton observes that even prior to the enactment of the PCMLA, concerns on confidentiality and reporting were noted and in 1999 the Canadian Bar Association ("CBA") had responded to requests from the Solicitor General of Canada for input on proposals to create Suspicious Transaction and Cross Border Currency Reporting regime by urging consultations with the legal profession. ${ }^{233}$ It was noted that the inclusion of lawyers and law firms in the category of persons or institutions required to report was "likely inconsistent with the duty of confidentiality which lawyers owe to their clients." ${ }^{234}$ Despite concerns expressed by the Federation in November 2001, the Federal government promulgated regulations making the PCMLA applicable to lawyers, and requiring legal counsel to secretly report suspicious transactions by their clients. ${ }^{25}$ Thus the Federation and the Law Society of British Columbia, supported by the Canadian Bar Association, initiated proceedings in the Supreme Court of the province of British Columbia challenging the constitutionality of the legislation and seeking interlocutory relief from the application of the regulations to legal counsel. ${ }^{23}$

In the matter of The Law Society of BC v AG Canada; Federation of Law Societies $v A G$ Canada ${ }^{237}$ the British Colombian Supreme Court exempted lawyers from compliance with the PCMLA pending a constitutional challenge of that Act. The legal regulators argued that the PCMLA would place vast amounts of information, unconstitutionally obtained, in the hands of government agencies, resulting in irreparable harm to the relationship of loyalty and trust between clients and legal counsel. ${ }^{238}$

The question of the appropriate balance between disclosure in the public interest and the broader protections of solicitor-client privilege was placed squarely at the heart of the parliamentary debate and later before the courts. ${ }^{239}$ The impact on the role of the place of the lawyer as gatekeeper, and the balance between a lawyer as an advocate of individual interest and as a protector of the broader public in the face of terrorism and other threats, remained important themes throughout. ${ }^{240}$

Further legal action by the Federation of Law Societies ${ }^{241}$ against the federal government lasted four years and was eventually adjourned without a decision

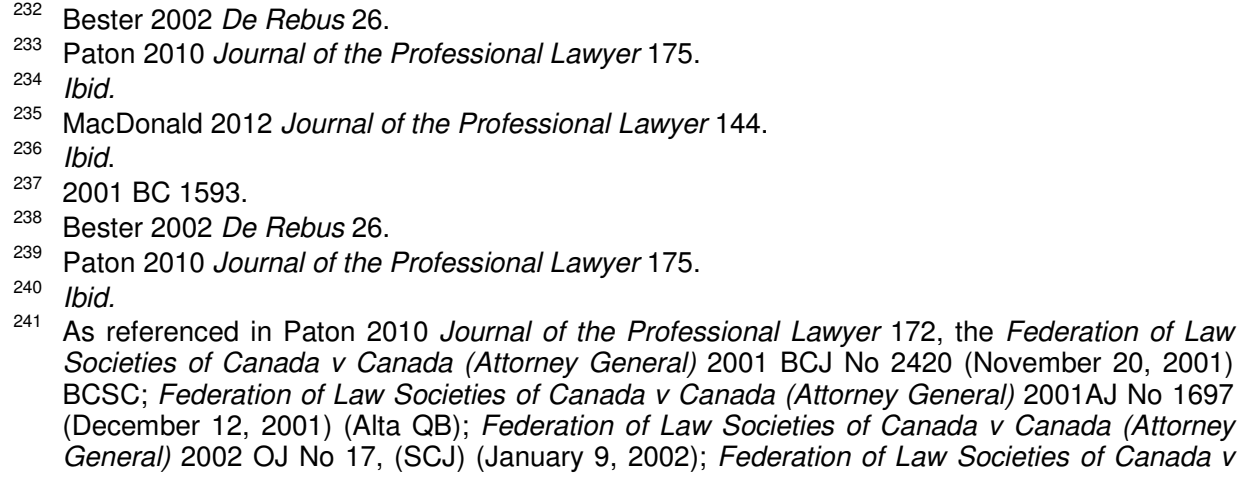


on the merits of the constitutionality of the impugned provisions. ${ }^{242}$ All these cases were based on the balancing of public and private interests in a similar way and none of which resolved the issue of where the balance should lie. ${ }^{243}$

The essence of the constitutional challenge in the matter of the Law Society of British Columbia v Canada (Attorney General) ${ }^{244}$ was that the PCMLA ${ }^{245}$ included obligations to report suspicious and prescribed transactions, and required lawyers to act as secret agents of the state, collecting information about clients against their interests and secretly reporting to a government agency. ${ }^{246}$ The contention was that the legislation threatened fundamental Canadian constitutional principles, which required that lawyers maintain an undivided loyalty to their clients, consistent with the independence of the bar and the integrity of the administration of justice. ${ }^{247}$

The British Columbia Supreme Court accepted these arguments, finding that the legislation represented "an unprecedented intrusion into the traditional solicitor-client relationship". ${ }^{248}$ The court granted an interim injunction exempting legal counsel from the requirement to report "suspicious transactions", pending a full hearing on the merits of the case. ${ }^{249}$ The British Columbia Court of Appeal affirmed the order, and the Supreme Court of Canada, Canada's highest court, denied the government's application to stay. ${ }^{250}$ As a result, in May 2002 the Attorney General of Canada agreed to suspend the application of the legislation to all Canadian lawyers, pending a final decision on the merits of the constitutional challenge to the legislation. ${ }^{251}$ At the time, the federal government indicated that following consultations with the legal profession, the government intended to put in place a new regulatory regime for lawyers that more appropriately reflected their duties. ${ }^{252}$ In the meantime, the parties agreed to adjourn the constitutional challenge indefinitely and all lawyers in Canada were to remain exempt from the legislation, and any new regulations, by virtue of the injunction. ${ }^{253}$

Canada (Attorney General) 2002 SJ No 200 (April 15,2002) (Sask QB); and Federation of Law Societies of Canada v Canada (Attorney General) 2002 NSJ No 1999 (April 17, 2002) (NSSC).

242 Paton 2010 Journal of the Professional Lawyer 172.

243 Paton 2010 Journal of the Professional Lawyer 173. For instance, in the matter of Federation of Law Societies of Canada v Canada (Attorney General) 2002 OJ No 17 (SCJ) par 42, it was concluded that: "Irrespective of the ultimate decision on the constitutionality of the legislation, there is no doubt that all the responsibilities that it will place on lawyers in their dealings with their clients will be onerous and will pose difficult questions with respect to the boundary line conflicting legal and continual ethical obligations." See also Paton 2010 Journal of the Professional Lawyer 173.

2442001207 DLR $\left(4^{\text {th }}\right) 705$ http://www.canlii.com/bc/cas/bcsc/2001/2001bcsc1593.html.

2452000 c 17

246 MacDonald 2012 Journal of the Professional Lawyer 144.

247 The Supreme Court of Canada in the matter of Maranda $v$ Richer 2003 SCC 67 http://www.canlii.org/en/ca/scc/doc/2003/2003scc67/2003scc67.html has affirmed that lawyers, who are bound by stringent ethical rules, must not have their offices turned into archives for the use of state authorities.

248 MacDonald 2012 Journal of the Professional Lawyer 144.

249 lbid.

250 Ibid.

251 MacDonald 2012 Journal of the Professional Lawyer 145.

252 Ibid.

253 Ibid. 
The government has since amended the PCMLA to exempt lawyers from the suspicious transaction-reporting requirements. ${ }^{254}$ The injunction and subsequent amendment of the legislation, coupled with the government's acknowledgement that the law societies are serious about exercising their mandate to regulate in this critical area, was an important victory. ${ }^{255}$

The Federation of Law Societies of Canada thereafter adopted its own initiatives to fight money laundering and terrorist financing, independently of the litigation. ${ }^{256}$ Over the past decade, the CBA has continued to intervene in most of the leading cases at the Supreme Court of Canada involving solicitor-client privilege ${ }^{257}$ Most recently, in the case of Ontario (Public Safety and Security) $v$ Criminal Lawyers Association, ${ }^{258}$ it was argued that without a strict application of solicitor-client privilege "access to justice and the quality of justice in this country would be severely compromised."

By voluntarily accepting responsibility to work against money laundering and terrorist financing, independent of Government action, law societies have, as suggested by MacDonald eliminated the need for federal regulation of the legal profession. ${ }^{259}$ It is the view of MacDonald that self-regulation in this regard is consistent with the best traditions of regulation of the profession. ${ }^{260}$ At its most basic level, the role of a law society is to regulate lawyers in the public interest. ${ }^{261}$ Preventing lawyers through appropriate law-society regulation from assisting, knowing or otherwise, any money-laundering activity and responding strongly to breaches of regulation promotes the public interest.

The Federation has also consistently stressed the importance of the independence of the bar which is free from the interference of state authorities is a critical component of the rule of law. ${ }^{263}$ Members of the public must have confidence in a system of justice that provides them with legal counsel who is free from the influence of the state. ${ }^{264}$

In this regard, in the matter of Finney $v$ Barreau du Quebec, ${ }^{265}$ where a decision of the Supreme Court of Canada dealt with the issue of the bar's independence, it was stated that: "An independent bar composed of lawyers who are free of influence by public authorities is an important component of the

\footnotetext{
254 Ibid.

255 MacDonald 2012 Journal of the Professional Lawyer 149.

256 Paton 2010 Journal of the Professional Lawyer 173.

257 Dodek "Solicitor-client privilege in Canada: Challenges for the $21^{\text {st }}$ Century" 2011 Discussion Paper for the Canadian Bar Association 13 , refers to, eg, the matter of Canada (Privacy Commissioner) v Blood Tribe Department of Health 2008 SCC 44 where the CBA asserted that "solicitor-client privilege is paramount and should be given priority to ensure public confidence in the administration of justice". In $R v$ Cunningham 2010 SCC 10, the CBA contended that "independence of the bar, and preservation of the privilege that protects solicitor-client communications are twin pillars in the fair and proper administration of justice in Canada". Furthermore in the matter of Lavelle, Rackel \& Heintz v Canada (Attorney General) 20023 SCR 209; and the CBA has argued that solicitor-client privilege "must be as close to absolute as possible" and that it is "essential to the rule of law".

2582010 SCC 23.

259 MacDonald 2012 Journal of the Professional Lawyer 149.

260 Ibid.

261 Ibid.

262 Ibid.

263 Ibid.

264 lbid.

2652004 SCC 36 (CanLII) http://canlii.org/en/ca/scc/doc/2004scc36/2004scc36.html.
} 
fundamental legal framework of Canadian society."266 Even though the constitutional issues raised by the Federation of the Law Society were never definitely answered, the judges in the respective matters discussed herein above have taken a clear view in that anti-money-laundering provisions compromising the legal professions' ethical duties towards their clients, is a difficult pill that shall not be swallowed.

\section{Comment}

It is evident that the position that Canadian courts have taken with regard to anti-money laundering reporting provisions is sui generis in that the legal profession has been allowed to remain self-regulated and separate. This unique stance of the Canadian courts is a result of years of litigation on the controversial aspects of the ethical rules of the profession versus the need to report suspicious transactions to circumvent organized crime. It is submitted that this is what the position should be if the profession wishes to protect the interests of the public. Taking this position, however, does put strain on the purposes sought to be achieved by the legislature in the enactment of moneylaundering provisions. Emphasis can only be placed on the need to balance the conflicting interests, a task which is no easy feat.

Canada has leaned towards the protection of the legal professional privilege rather than the enforcement of anti-money-laundering reporting provisions. But, where is the line to be drawn? At some point, pragmatism takes over and one must accept that terrorist-funded activities for example, have their source of income from countries whose protection over their financial sector is less than a good reflection of the international standards. Does the fact that the constitutions of Canada and South Africa are similar make any inroads into the discussion thus far? Can this be where jurists differ on the interpretation of some of the rights at play? It seems, however, given the comparison between the positions in Canada and South Africa, that no matter how similar the legal systems are to each another, it is not a decisive factor to be taken into account.

Perhaps the fact that Canada has been successful in overriding the duty to report in the legal profession (to the extent that South Africa and the UK have not) is because Canadian lawyers have not only voiced their concerns, but have gone so far as to challenge the said anti-money-laundering provisions in court. Despite many opinions regarding this controversial topic in the South African sphere, it has yet to be challenged, and until then legal professionals will not have clarity.

266 MacDonald 2012 Journal of the Professional Lawyer 149; and 2002 OJ No 17 par 42 as referred to in Paton 2010 Journal of the Professional Lawyer 180. In the matter of Federation of Law Societies of Canada $v$ Canada (Attorney General) Justice Cullity also neatly summarized the potential consequences of the legislative reforms: "In imposing a duty on legal practitioners to give secret reports of their clients' transactions to a government agency, the legislation clearly impunges on, and alters, the traditional relationship between solicitors, or counsel, and their clients. It does not merely override a lawyer's ethical duty of confidentiality - something that has always been possible in legal proceedings with respect of matters not subject to solicitor-client privilege - it strikes at the lawyer's duty of loyalty and the client's privilege against self-incrimination as well as the principle that lawyers should be independent from the government. The duty of loyalty is affected not only by the obligation to make secret reports to Government about a client's transactions and personal details, but, also because of the inevitable involvement of the lawyer's personal interests and potential liability to serve penalties when decisions whether to report are to be made." 


\section{The United Kingdom}

\section{General}

The common law in the UK with regard to the rules of privilege and confidentiality is that there is an absolute privilege as to communications between a lawyer and a client in relation to legal proceedings, whereby such information is inadmissible as evidence in a court of law. ${ }^{267}$ The scope of legal professional privilege is broad as it also extends from the position between a lawyer and his client to legal advice outside the context of on-going litigation. ${ }^{268}$

The UK no longer uses the term "solicitor-client privilege" except in historical references and like South Africa refers rather to "legal professional privilege". ${ }^{269}$ The law of professional privilege applicable in South Africa is as it was in the English law on 30 May $1961 .{ }^{270}$ The similarity between these two legal systems is that there exists a doctrine in both South African common law and UK common law that confidential communications between an attorney and his client are "privileged" from disclosure. ${ }^{271}$

According to Halsbury, a solicitor cannot be compelled to disclose communications, whether oral or written, passing directly or indirectly between him and his client, between him and a person who is communicating with him professionally with a view to becoming his client, for the purpose of giving or receiving legal professional advice, if they are legitimate communications in the sense that they are not made in the furtherance of fraud or crime. ${ }^{272}$ The privilege extends to information which a solicitor receives in a professional capacity from a third party, and which is then conveyed to the client. ${ }^{273}$ The effect of privilege is that neither the client, nor the solicitor without his consent can be compelled to disclose the communication in the course of legal proceedings. ${ }^{274}$ The privilege is that of the client, not the solicitor's and until the client has waived the privilege it is the solicitor's duty, if he is requested to make disclosure, to claim the privilege. ${ }^{275}$

In Price Jefry Bolkiah $v$ KPMG ${ }^{276}$ the professional duty of confidentiality was considered in detail. Lord Hope stated that it "extends well beyond that of

267 Bennett A Practitioner's Guide to Money Laundering Compliance 57.
268 Ibid.
269 Dodek 2011 Discussion Paper for the Canadian Bar Association 18.
270 Schmidt and Zeffert in Joubert and Faris (eds) The Law of South Africa Vol 2503 par 754 .
271 Hoffmann Legal Education And Development, Law Society of South Africa Professional
Conduct 27 .
272 Lord Hailsham Halsbury's Laws of England Vol 44(1) (1995) 71 .
Ibid.
Ibid.
Ibid. Lord Taylor of Gosforth CJ in R v Derby Magistrates Court ex parte B 19961 AC 487507
remarked: "A man must be able to consult his lawyer in confidence, since otherwise he might
hold back the truth. The client must be sure that what he tells his lawyer in confidence will
never be revealed without his consent. Legal professional privilege is thus much more than an
ordinary rule of evidence, limited in its application to the facts of a particular case. It is a
fundamental condition on which the administration of justice as a whole rests." (As referred to
in Alldridge Money Laundering Law, Forfeiture, Confiscation, Civil Recovery, Criminal
Laundering and Taxation of the Proceeds of Crime (2003) 265).
19992 AC 222 as referred to in Bennett A Practitioner's Guide to Money Laundering
Complance 58 . Compliance 58. 
refraining from deliberate disclosure". ${ }^{277}$ In the more recent $R v$ Special Comrs \& Anor ex $p$ Morgan Grenfel P $^{78}$ Lord Hoffmann restated that "the policy of legal professional privilege requires that the client should be secure in the knowledge that protected documents and information will not be disclosed at all."

The duty of confidence and legal professional privilege are protected. Not only is this duty upheld in common law and case law, but it can also be observed in principle 2.3.3 of the Law Society's Guide to Professional Conduct where confidentiality was declared to be "a primary and fundamental right and duty of the lawyer" and is (or was) the essence of a lawyer's function. ${ }^{279}$ However, a solicitor has a legal obligation to notify the police if he has reason to suspect his client of being involved in money laundering and in those circumstances he has no right to rely on professional privilege as to the communications between himself and his client if they are made with a view to furthering any criminal purpose. ${ }^{280}$

\section{Anti-money-laundering legislation}

As with South Africa and Canada, there is specific legislative targeting of the crime of money laundering in the UK. Legislation that was enacted for the purpose of combating money laundering in the UK is summarized below. The Criminal Justice $\mathrm{Act}^{281}$ ("CJA") extended the scope of previous UK anti-moneylaundering offences from specifically defined crimes such as drugs and terrorism to the non-specific category of other "serious crimes" pursuant to the first and second European Union anti-money-laundering directives. ${ }^{282}$ The principle money-laundering offences created by the CJA were as follows: ${ }^{283}$

- Assisting the retention or control of the proceeds of criminal conduct by another, knowing or suspecting others to be involved in money laundering;

- acquisition possession or use of proceeds of criminal conduct, knowing the property concerned to be tainted; and

- concealing or transferring property, knowing or having reasonable grounds to suspect that property is the proceeds of criminal conduct.

The Proceeds of Crime $\mathrm{Act}^{284}$ ("POC") replaced the anti-money-laundering provisions of the CJA as well as other anti-money-laundering legislation such as the Criminal Justice Act 1998 as well as the Drug Trafficking Act 1994. ${ }^{285}$ The POC restates the money-laundering offences, replacing the parallel drugand non-drug crime money-laundering offences with single offences that do not

27719992 AC 222 236. Lord Millet in the same matter stated: "It is of overriding importance to the proper administration of justice that a client should be able to have complete confidence that what he tells his solicitor will remain secret. This is a matter of perception as well as substance."

2782002 UKHL 21 as referred to in Bennett A Practitioner's Guide to Money Laundering Compliance 58.

279 Bennett A Practitioner's Guide to Money Laundering Compliance 57.

280 Lord Hailsham Halsbury's Laws of England Vol 44(1) 72.

2811993.

282 Bennett $A$ Practitioner's Guide to Money Laundering Compliance 4.

283 Ibid.

2842002.

285 Bennett A Practitioner's Guide to Money Laundering Compliance 5. 
distinguish between the proceeds of drug trafficking and other crimes. ${ }^{286}$ Section 330 of the POC deals with a failure to disclose, and introduces a negligence test for liability under this offence, or negligently failing to report a money-laundering offence. ${ }^{287}$

The offence is committed if the following three conditions are satisfied: ${ }^{288}$

- A person knew or suspected, or has reasonable (that is objective) grounds for knowing or suspecting, that another person is engaged in money laundering, even if he/she did not actually know or suspect;

- the information or other matter on which the knowledge or suspicion is based, or which gives reasonable grounds for such knowledge or suspicion, came to the person in the course of a business in the "regulated sector"; and

- the person failed to report the information or suspicion of money laundering by means of a suspicious activity report to the authorities as soon as practicable after it came to that person.

The provisions of the POC apply to those working in the UK's "regulated financial sector" which includes accountants, lawyers, trustees and many other categories. ${ }^{289}$ However, section 330(10) of the POC contains an exception for the need to report privileged information or other matter which comes to a professional legal adviser in privileged circumstances if it is communicated or given to him:

"(a) by (or by a representative of) a client of his in connection with the giving by the adviser of legal advice to the client;

(b) by (or by a representative of) a person seeking legal advice from the adviser; or

(c) by a person in connection with legal proceedings or contemplated legal proceedings."

Section $330(11)$ of the POC excludes from the "privilege defence" information or other matters which are communicated or given with the intention of furthering a criminal purpose. ${ }^{290}$ This overriding duty to the state is also reflected in principle 16.02 of the Law Society's Guide to Professional Conduct which allows a solicitor to report his client to the authorities rather than be dragged into providing assistance in the perpetration of a crime. ${ }^{291}$

The Money Laundering Regulations ${ }^{292}$ ("MLR") must also be noted. These were first published by the UK Treasury in 1999, revised in 2003, replaced in 2007 and further amended in 2012 by the Money Laundering (Amendment Regulations). ${ }^{293}$ The MLR 2007 came into force on 15 December 2007 applies

\footnotetext{
286 Ibid.

287 Bennett A Practitioner's Guide to Money Laundering Compliance 8.

288 Bennett A Practitioner's Guide to Money Laundering Compliance 4.

289 Bennett A Practitioner's Guide to Money Laundering Compliance 8.

290 Bennett A Practitioner's Guide to Money Laundering Compliance 59.

291 Ibid.

2922007 No 2157.

2932012 No 2298.
} 
to "relevant persons" acting in the course of business carried on by them in the UK, which inter alia includes independent legal professionals. ${ }^{294}$

The MLR 2007 also sets out administrative requirements for the anti-moneylaundering regime and sets out the scope of customer due diligence. It is interesting to note that the reporting requirements set out in the MLR 2003 have also been replaced and neither is there any mention in the MLR 2007 for provision of the protection of legal professional privilege.

There is an obvious concern to solicitors with regard to the conflict that is created in terms of anti-money-laundering legislations requiring disclosure, where a non-disclosure amounts to severe penalties for solicitors. ${ }^{295}$ The maximum penalty for the offence is five years' imprisonment and/or an unlimited fine. ${ }^{296}$ The fact that anti-money-laundering laws and -procedures have entirely changed the position of professionals and practitioners in terms of their traditional duty of confidentiality towards their clients. ${ }^{297}$ Bennett resolves, however, that part of the solution is to make prospective, as well as existing clients clearly aware at the "prospect" stage or the latter by means of a circular or notice attached to the next fee note, that public duties now outweigh the duty of confidentiality. ${ }^{298}$ Clients therefore need to be aware of the possibility that, if the attorney has any future suspicions, that it could lead to them being reported. ${ }^{299}$ Bennett holds that perhaps this outcome is the result of the UK not having a written constitution that has allowed such a long-standing commonlaw principle of legal professional privilege effectively to be swept aside..$^{300}$

Paton submits that these changes to lawyer regulation in England discussed above are indicators of government becoming "less inclined to bow to lawyers' traditional role as governors of their own profession" and that the UK has implemented a more stringent anti-money laundering regime as well as obligations for lawyers beyond what is required by FATF guidance..$^{301}$

$2943(1)(d)$ MLR 2007. According to the MLR independent legal professionals are defined in MLR 2007 as the following, namely: "a firm or sole practitioner who by way of business provides legal or notarial services to other persons, when participating in financial or real property transactions concerning - (a) the buying and selling of real property or business entities; (b) the managing of client money, securities or other assets; (c) the opening or management of bank, savings or securities accounts; (d) the organisation of contributions necessary for the creation, operation or management of companies; or (e) the creation, operation or management of trusts, companies or similar structures, and, for this purpose, a person participates in a transaction by assisting in the planning or execution of the transaction or otherwise acting for or on behalf of a client in the transaction."

295 Bennett A Practitioner's Guide to Money Laundering Compliance 59.

296 Bennett $A$ Practitioner's Guide to Money Laundering Compliance 8. In the matter of $R v$ Duff (2003 Vol 10 No 2 as referred to in Bennett A Practitioner's Guide to Money Laundering Compliance 63), a solicitor in England named Jonathan Duff was imprisoned for six months by the Manchester Crown Court for the anti-money-laundering offence of failing to report his suspicion in relation to money paid to his firm by a commercial client who was then convicted of drug trafficking. Duff misunderstood the reporting suspicion which may be due to the ambiguous wording of the statute, but despite this he was still sent to prison.

297 Bennett A Practitioner's Guide to Money Laundering Compliance 55.

298 Ibid.

299 Ibid.

300 Bennett A Practitioner's Guide to Money Laundering Compliance 59; and Lavalee Rackel and Heintz v Canada (A-G) 2002 SCC 61; Law Society of British Columbia v A-G of Canada 2000 BC Supreme Court 1593.

301 Paton 2010 Journal of the Professional Lawyer 168. 
Although the UK's Regulations applicable to solicitors have been in force for a number of years, the incorporation of the procedures into standard practice, has been slow. Even though the solicitors may be aware of the laws, they are mindful not to compromise their duties to clients. ${ }^{302}$ Reporting one's suspicion that a client may be engaging legal services in order to legitimise-tainted funds is incongruous with the entrenched principle of confidentiality. ${ }^{303}$ However, on the other hand, compliance with the reporting obligations is highly encouraged because it provides solicitors with an escape from the likelihood of prosecution. ${ }^{304}$ This is in fact more ideal. Solicitors should be able to discourage their clients from engaging in illegal activities without being forced to breach their duties towards clients. Fear of prosecution and being implicated in illegal activities will force solicitors to act professionally towards their clients and to discourage them from participating in illegal activities.

This double-edged sword is particularly unfair on legal professionals who face a predicament in the view to furthering of the interests of the state. Where the legal profession is already one which is self-regulated, they now must face more government regulations which prove onerous as well as threatening to the independence of the profession. Their clients' trust and confidence in the profession is at risk. Even though attorneys are not the only accountable institutions that are trying to balance their rights against their clients' rights against the interests of the state, it is a profession that revolves around attorney-client confidentiality.

Banks and financial institutions were also traditionally known to afford confidential services that allow for the concealment of illegally obtained money. ${ }^{305}$ However, the fact that client privacy is also closely regarded in the financial sector, especially with regard to banking activities, the imposition of reporting requirements has not been thwarted because the procedures are legitimately within the authority of its regulators. ${ }^{300}$

Designating financial institutions with reporting responsibilities is the norm among the anti-money-laundering procedures in many jurisdictions and is endorsed by the FATF. ${ }^{307}$ Abendano rightfully submits in her article that placing similar obligations upon the legal profession appears problematic, however, because unlike financial institutions, lawyers are independent professional advisors. ${ }^{308}$ Lawyers place a high significance on the privacy of their dealings with clients and view intrusions as threatening to the integrity of the profession. ${ }^{309}$

Even though Abendano acknowledges that requiring UK solicitors to report their suspicions regarding a client is contradictory to the fundamental duties of confidentiality and privilege that attach in a solicitor-client relationship, ${ }^{310}$ she notes that due to the UK's strong public policy against money laundering, an

302 Abendano "The Role of Lawyers in the Fight Against Money Laundering: Is a Reporting Requirement Appropriate?" 2001 Journal of Legislation 463470.

303 Abendano 2001 Journal of Legislation 470.

304 Ibid.

305 Abendano 2001 Journal of Legislation 471.

306 Ibid.

307 Ibid.

308 Ibid.

309 Ibid.

310 Abendano 2001 Journal of Legislation 472. 
occasional divergence from standard legal professional norms may be justified. ${ }^{31}$

It seems that even though the right to legal professional privilege is fundamental to the attorney's profession, is entrenched in common law, protected by case law as well as by the principles of the UK Law Society, then there is a rationale as far as money laundering is concerned, behind the UK that enacted onerous reporting provisions against attorneys. Attorneys are utilized by money launderers to "legitimise" the proceeds of crime.

UK money-laundering laws treat privilege much like confidentiality by protecting solicitors against professional misconduct. ${ }^{312}$ Under the UK regime, providing authorities with information does not constitute a waiver of privilege as long as it is performed within the context of a criminal investigation. ${ }^{313}$ Furthermore, by protecting barristers and solicitors against potential breaches of their professional obligations, UK laws attempt to facilitate the cooperation of the legal community when a criminal investigation of financial crime takes place.

The difficulty in regulating the legal profession in the same manner in which the financial sector has been monitored is in the intrusion upon a professional community that places a high premium on confidentiality. ${ }^{315}$ Abendano submits in this regard that the only way in which this measure involving the legal community will work is if it does not interfere significantly with lawyers' obligations to their clients. ${ }^{316}$ In addition, government control of a body of professionals designated with the duty to assist clients in their private endeavours may result in a division of lawyers' loyalties. ${ }^{317}$ Confidence in the impartiality and independence of lawyers would erode and directly impact the quality of advice that legal professionals could offer to clients. ${ }^{318}$

\section{Comment}

The UK has seemingly moved towards a position where the ability of the legal profession to be independent and self-regulated is not protected, holding more important their duties towards the state, slowly and inevitably eroding the fundamental rule of legal professional privilege. In so doing, however, and it must not be disregarded, this strict approach to money-laundering provisions trumping legal professional privilege may have the result that the UK is less attractive as a haven for organized-crime syndicates. The pertinent question is, therefore, whether the cost of crime prevention is the degradation of the legal professions' code of ethics, and whether this price is too high.

Even though both Canada and the UK, like South Africa have duties in places that can be traced back to common law in the case of the UK and Canada and to Roman-Dutch law in the case of South Africa, both countries

\footnotetext{
311 Ibid.

312 Abendano 2001 Journal of Legislation 473.

313 Ibid.

314 Ibid.

315 Ibid.

316 Ibid.

317 Abendano 2001 Journal of Legislation 474.

318 Ibid.
} 
have enacted legislation in order to combat money laundering. The common effect that this legislation has had on attorneys' rights to legal professional privilege has been damaging. Again, the question to be answered is whether crime prevention should be placed on a higher pillar of enforcement at the mercy of the legal profession's ethical code, which has its own very important contributions to the administration of justice and client's constitutionally protected rights (at least in Canada and South Africa).

From the discussion on the position in Canada, legal professionals through their law society challenged the onerous anti-money-laundering provisions in court and did so successfully, preserving their common-law duty of professional privilege under the regulation of its law society.

In the UK, however, regardless of whether lawyers are governed by their own law society, the courts have followed a strict observance of the legislation in order to combat money laundering. This is partly attributable to the fact that the UK does not have a supreme Constitution with which to test its Parliament's legislation. This is in contrast to the Canadian and South African constitutional dispensation. Indeed, the fact that the UK's parliamentary sovereignty has placed money-laundering provisions at the heart of the debate is no surprise. The effectiveness of the choice, in either of the chosen countries in this paper, is yet to be seen. Whether or not the UK has reduced its attractiveness to organized crime is beyond the scope of this paper. Suffice it to say that, if so, then a pat on the proverbial back may not be forthcoming if the cost of the disincentive is the crippling of the legal profession and its need to be selfregulated for purposes of certainty and paramount ethical standards. Therefore, viewed holistically, the question is: What have we learnt from these comparisons in South Africa? More importantly whether South Africa has the right framework in place to enable it to balance the tightrope between enforcing anti-money-laundering provisions successfully and safeguarding legal professional privilege.

\section{CONCLUSION}

One can only speculate on the effectiveness of the current statutory measures as these apply to attorneys. Nevertheless, they do make certain recommendations which are aimed at assisting the legal professional in complying with anti-money-laundering reporting obligations. South African lawyers must report their clients to the FIC for money-laundering offences in terms of FICA because they fall within the definition of "accountable institution". This creates tension for attorneys between FICA's reporting obligations on the one hand and the attorneys' clients' rights to legal professional privilege on the other. The ability of attorneys to render their professional services are compromised as clients will not be as eager to consult openly, in confidence and without fear, if they know that they may be reported. In addition, it is submitted that attorneys should be trusted not only to discourage their clients from participating in illegal activities such as money laundering but also to advise clients of the consequences of their actions. Furthermore, the ethics of the legal profession dictate that attorneys who are aware of their clients' involvement in illegal activities should act in a way they see fit. For instance, an attorney who has advised a client of the dangers involved in their illegal behaviour may terminate the relationship with that client and formally distance himself from the client's illegal activities. However, FICA creates the impression 
that attorneys cannot be trusted to do what is right and that they should now be burdened with additional statutory obligations.

In Canada, the legal profession voluntarily adopted client-identification and record keeping requirements, which in the end effectively implemented the FATF initiatives while neatly sidestepping the creation of a positive duty to report. ${ }^{319}$ Federal legislation was designed to implement FATF initiatives and set the stage for direct confrontation between the public interest and the legal profession's protection of what it considered to be its core values. ${ }^{320}$ The UK, on the other hand, has taken it to the extreme by so called "gold-plating" the underlying European directive, leading to lawyers making thousands of suspicious transaction reports a year. ${ }^{321}$ Solicitors have even gone to prison for not reporting transactions that the courts have subsequently ruled about which they should have had their suspicions. ${ }^{322}$ In the UK privilege remains a common-law doctrine which is subject to legislative restrictions in accordance with the doctrine of parliamentary supremacy. ${ }^{32}$

It is submitted that there is no need to regulate the South African professional legal industry any further. Until FICA's reporting provisions are formally challenged in the Constitutional Court, attorneys will continue to remain uncertain as to their position, notwithstanding the fact that guidance notes have been issued to aid attorneys in this regard. As harsh and burdensome as it is for legal professionals, there is, still a statutory obligation to comply with the reporting duties, and to consult whenever possible, with the guidance notes.

How then does one comply with FICA and simultaneously preserve the attorney-client relationship? First, it is necessary to educate clients on the provisions of FICA, and especially on the attorney's duty to report. In practice this means that new clients can and should be made aware of an attorney's duty to report in an engagement letter. ${ }^{324}$

Second, legal practitioners should have a sound legal knowledge of FICA in order help the State combat organized crime and laundering activities. ${ }^{325}$ The LSSA's guidance notes set out the rules and procedures. ${ }^{326}$ It is submitted that these aspects should be thoroughly assessed in the attorneys' admittance exam.

In the third instance, it is advisable to keep up to date with the latest guidelines regarding the independence of the profession and possible infringements of the fundamental right to privacy and potential threats to the confidential attorney-client relationship. Because of the overriding professional duty owed by attorneys to their clients, it is important that in complying with their obligations under FICA, attorneys do not divulge information or furnish records or documents to the FIC furnished to them in their capacity as

\footnotetext{
319 Paton 2010 Journal of the Professional Lawyer 171.

20 Ibid.

321 Rose 2009 International Bar News 38.

22 Ibid.

323 Dodek 2011 Discussion Paper for the Canadian Bar Association 18.

324 Van der Westhuizen July 2004 De Rebus 34.

325 Hoffmann Legal Education And Development, Law Society of South Africa Professional Conduct 21.

326 Ibid.
} 
attorneys in confidence by, or on behalf of, their clients, with which they need not necessarily part. ${ }^{327}$ What is considered necessary would be determined on a case-by-case basis. It is advisable that attorneys in each instance consider carefully the extent of the disclosure to be made, or and whether privilege may be invoked as provided in section 37(2) of the FICA, either in respect of all, or part of, the information or documentation sought. ${ }^{328}$ Privilege should be claimed in favour of clients to the full extent appropriate in the given circumstance ${ }^{329}$ It is the awareness of this balance that will ensure compliance with the FICA without causing the attorneys' profession to lose its credibility and even though the requirements of FICA seems like a dramatic invasion to the legal profession's duties towards its clients, there is a legitimate purpose for doing so.

\footnotetext{
327 Guideline: FICA 10.

328 Ibid.

329 Ibid.
} 